Article

\title{
A Multi-Perspective View on Immersive Virtual Environments (IVEs)
}

\author{
Olaf Kühne ${ }^{1}$, Dennis Edler ${ }^{2}(\mathbb{D})$ and Corinna Jenal ${ }^{1, * \mathbb{D}}$ \\ 1 Department of Geosciences, Urban and Regional Development, Eberhard Karls University of Tübingen, \\ Rümelinstr. 19-23, 72070 Tübingen, Germany; olaf.kuehne@uni-tuebingen.de \\ 2 Institute of Geography, Ruhr University Bochum, Geomatics Group, Universitätsstr. 150, \\ 44801 Bochum, Germany; dennis.edler@rub.de \\ * Correspondence: corinna.jenal@uni-tuebingen.de; Tel.: +49-(0)7071-29-77535
}

Citation: Kühne, O.; Edler, D.; Jenal, C. A Multi-Perspective View on Immersive Virtual Environments (IVEs). ISPRS Int. J. Geo-Inf. 2021, 10, 518. https://doi.org/10.3390/ ijgi10080518

Academic Editor: Wolfgang Kainz

Received: 15 April 2021

Accepted: 28 July 2021

Published: 31 July 2021

Publisher's Note: MDPI stays neutral with regard to jurisdictional claims in published maps and institutional affiliations.

Copyright: (c) 2021 by the authors. Licensee MDPI, Basel, Switzerland. This article is an open access article distributed under the terms and conditions of the Creative Commons Attribution (CC BY) license (https:// creativecommons.org/licenses/by/ $4.0 /)$.

\begin{abstract}
In recent years, the presence of immersive virtual reality (VR) in everyday life has increased, and VR is also being studied in research. However, this research is essentially limited to technical issues, while the social relevance of VR remains largely unconsidered. Current social science research on VR remains bound to an empiricist paradigm; a theoretical framing is only done in exceptions. This article presents current social science theories related to space and landscape research, describes their application and potentials, with regard to the investigation of virtual spaces, and discusses which theoretical positions are suitable for the investigation of particular immersive VR-related questions. This investigation presents a range of approaches such as essentialism, positivism, and constructivism; theories such as critical, conflict, and discourse; and more-than-representational theories such as Phenomenology, Assemblage, and Actor-Network-Theory.
\end{abstract}

Keywords: virtual reality; VR; spatial theory; landscape theory; social sciences; constructivism; more-than-representational theories; critical theory; conflict theory

\section{Introduction}

In recent years, the everyday presence of immersive virtual environments (IVEs) has increased. With the proliferation of game engines (e.g., Unreal Engine, Unity) and VR systems, including VR headsets and sensor tracking systems, immersive virtual landscapes have become part of home entertainment, as well as creative engagement through $3 \mathrm{D}$ visualization in personal and multidisciplinary professional contexts, since the mid-2010s. Scientific use also took off, though VR application in the geoinformation sciences initially remained strongly limited to technical and applied engagement, and less to the effects of case studies constructed in VR [1,2]. Theoretical framing was largely absent, with a few-rather exploratory-exceptions (e.g., in [3-7]), resulting in a thicket of individual studies on this topic which requires a foundational orientation to navigate. In social science research on space and landscape, there has been an intensive discussion in the last decades about theoretical frameworks of the relationship of human beings to their material and social environment, but also about the development of the social environment and its impact on the material environment. This can - as we will show-be used for the theoretical framing of the relationship between man/society and VR. This theoretical framework is necessary not least because the number of individual investigations of these relationships has meanwhile assumed a scope that requires a categorical order. Furthermore, theory offers the possibility to derive empiric studies in a meaningful way, so that they do not investigate details without direction (more on this: [8,9]). Accordingly, the present paper first outlines the need for a theoretical approach to virtual realities (Section 2). Subsequently, we will address the current state of VR research, which serves as the basis for possibilities and limitations for the different theoretical approaches (Section 3). The second basis is formed by theories discussed in current spatial and landscape research (Section 4). These 
form a solid starting point for a theoretical approach to virtual realities in relation to the construction of spaces. In the following, the different theoretical approaches will be examined in terms of their potential for addressing virtual realities (Section 5). The final conclusion will emphasize the necessity of different theoretical approaches to VR, and offer perspectives for future theoretical approaches to immersive virtual environments (Section 6).

While there has been a long period of dealing with virtual realities in spatial sciences (e.g., $[10,11])$, new technological innovations, especially head-mounted displays (HMDs) and sensor tracking systems transferring real-time body movements, make it possible to intensify a vivid illusion of being present in a (multisensory) virtual environment [12]. From a technological point of view, this illusion of being present in a virtual environment, with different potential qualities, can refer to the term immersion [13]. We consider immersive virtual environments as constructed media, strongly related to the fields of cartography and geo-visualization. These media built the (technical) base for analyzing the potentials of the established theoretical positions from social sciences.

\section{On the Necessity of a Theoretical Examination of the World-In This Case, Virtual Reality}

There are several reasons to support a theoretical framing in an evolving research context $[14,15]$. A theoretical approach to an object (in this case, virtual realities) facilitates abstraction from and investigation of the multitude of individual cases, and thus facilitates orientation in the emerging thicket of individual cases and single case investigations. The latter often do not tie themselves to scientific theoretical discourses or do so only implicitly; a theoretical framing thus enables their subsequent ordering. In terms of research practice, theories alone are not suitable for framing empirical research, but empirical research can in turn test the degree of generalizability of theories. Another practical research significance of theoretical engagement with virtual realities is facilitating connectivity to different scientific disciplines (such as the social sciences, psychology, geography, or philosophy). Two further reasons for theoretical engagement refer to questions of genesis and contextualization of knowledge: first, the topical question of how 'the normal', the 'selfevident', and the 'everyday' are created within virtual realities and how they are separated from deviations from them; how research programs are created; how methodological approaches are developed; and, last but not least, how consensual validation of statements about the world is achieved $[16,17]$. Second, engagement with theoretical approaches to VR enables a multiplicity of ways to investigate a research object. This offers the possibility to contextualize and better justify one's own ideas (including theoretical ones) about the object, and ultimately gain deeper insight into the variety of possible perspectives on the world.

To make this clearer for research on immersive VR-immersive VR is not only a technology, but it affects individual consciousness, and above it also social contexts, enabling previously unknown forms of socialization and reference to simulated spaces. The social sciences have developed a wide range of theoretical approaches to these relationships, which deal with individual references. From these approaches, certain methodological approaches emerge to investigate these references. For example, one can ask what socialization conditions must exist in order to see landscapes in the immersive virtual world; here, a social constructivist theoretical framing would be adequate, since this theory is strongly concerned with the relationship between society and the individual; methodologically, it is often associated with qualitative approaches (such as interviews, participant observation).

\section{Research Approaches to Immersive VR Landscapes in Geographic Information Science}

The freely accessible release of established game engines from the mid-2010s (especially Unreal Engine) gave 3D visualization a fundamental new impetus. Game engines enable the recreation of real-space or the creation of fictitious 3D landscapes that can be explored from a first-person perspective with a controllable avatar in real time. Through 
this real-time control, these virtual 3D landscapes extend to other possibilities for deriving spatial three-dimensional media, such as map-related representations from an oblique perspective in which (freely available) digital terrain models are blended with aerial image textures (Figure 1).

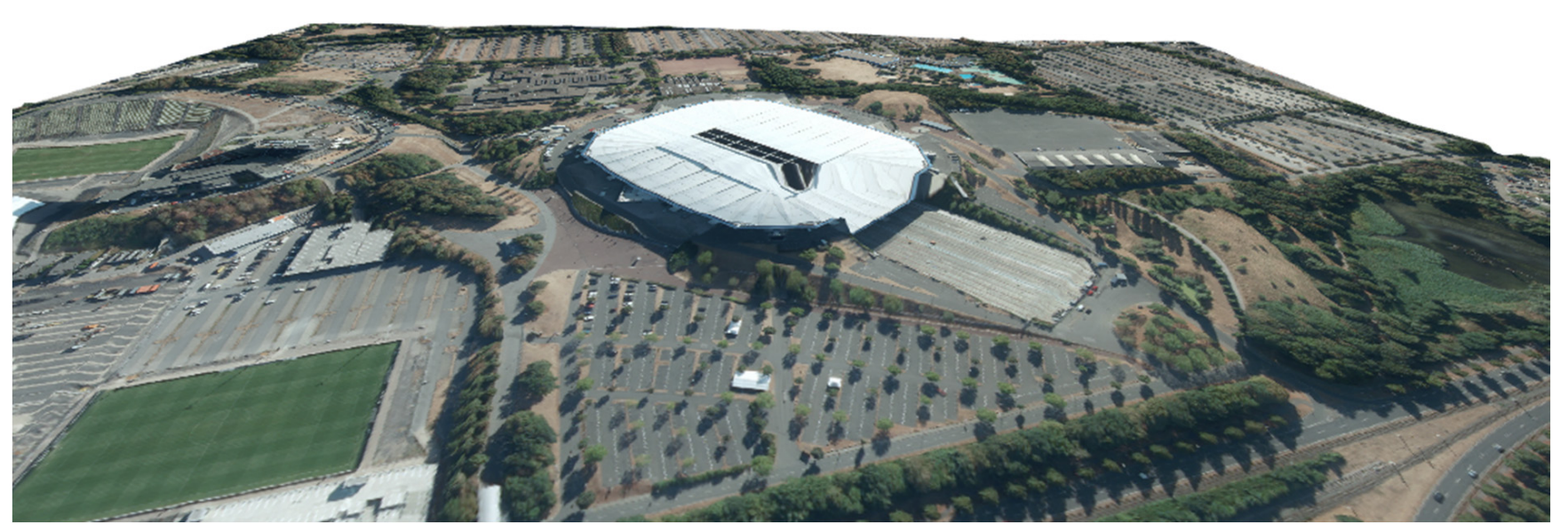

Figure 1. Static 2.5D impression of the FC Schalke 04 stadium area (own representation by Dennis Edler and Timo Wiedenlübbert).

Technically, this experience of created 3D virtual landscapes can be enhanced using established mass hardware systems. VR headsets coupled with sensor tracking have been shown to enhance the immersion effect, i.e., the consciousness of perceiving a virtual environment as real. Interacting in a virtual environment from a first-person perspective through a VR headset in real time increases the intensity of immersion, e.g., as compared to movies or to desktop applications [18].

The current scientific literature in geoinformation sciences points to several research foci, in particular: (1) the technical optimization in the (process-automated) derivation and design of immersive 3D landscapes, (2) the construction and discussion of application scenarios of immersive 3D landscapes, and (3) user- and cognition-oriented evaluation in the interaction with immersive 3D landscapes.

New approaches to designing immersive 3D landscapes include, for example, deriving photogrammetrically accurate terrain representations [19] and city models [20,21]. The integration of official as well as voluntarily collected geodata, which are increasingly offered via open data initiatives to businesses, government, and society, is also used to prospectively prepare geospatial data resources for further processing with transferable methodological approaches for game engines (see [22,23]). Some recent approaches also point to the potential for multisensory enhancement of geospatial data by integrating acoustic and olfactory designs to convey factual spatial content in immersive 3D landscapes [6,24,25]. Beyond spatial data, technical data on infrastructures within VR environments is also being examined (see, e.g., [26-28]).

While the source data for deriving immersive 3D landscapes is always being optimized by technologies and new methods, applied VR studies in geoinformation sciences focus on the creation and analysis of case studies to project outcomes. Early debates on virtual realities - in the context of Virtual Geographic Environments (VGEs) - focused on the dynamic 3D visualization of environmental systems and processes $[26,29,30]$. VR-based simulations of dynamic human behavior were also taken up in early research [31,32]. Current applied case studies with immersive 3D landscapes cover a diverse range of topics in geoinformation science. Relevant examples are urban and regional planning [33-35], location-based marketing [36], noise pollution [37], audiovisual traffic simulation [38], climate change [39], disaster simulation [40], biodiversity [13], tourism and cultural heritage [41-43] and geography education [44,45]. In contrast to the landscape in real-space, physical and also legal boundaries can be crossed in virtual environments, such as entering secured construction sites, moving on sidewalks at excessive speed or by teleporting, or 
passing through or entering certain surfaces, objects and materials (Figure 2). From these experiences, which are only possible in virtual space, new experiences and perspectives on the represented space can be gained.

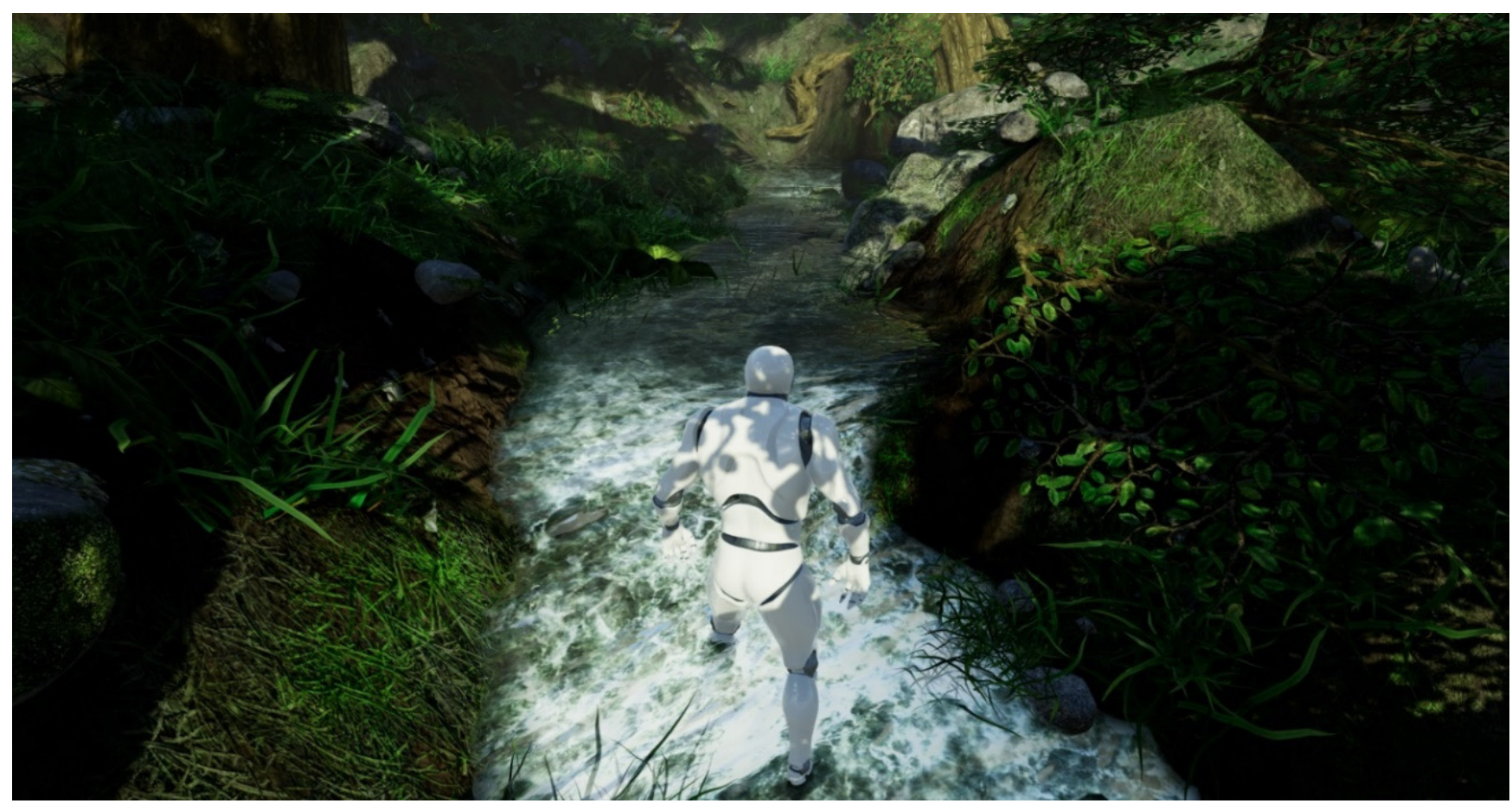

Figure 2. Virtual spatial experience from a flowing body of water in a forest landscape (own illustration by Dennis Edler and Timo Wiedenlübbert).

To enable the most effective and efficient use of these VR applications, insights from cognitive research and human-computer interaction (see, e.g., [46]) are required for their design, as has been known for decades in basic research on 2D cognitive mapping (see [7-49]). In virtual reality, cognitive processing of information presented in immersive 3D landscapes, including the portrayal of a cognitive representation of an experienced space in memory [50,51], is coupled with a virtual spatial experience from a first-person perspective. This differs significantly from the familiar processing of a generalized 2D cartographic floor plan representation [18], and requires knowledge on user-oriented design and interaction with orientation and navigation aids. Examples are artificial signifiers or constraints [23] as well as mini-maps used in gaming [52]. In addition, there are new forms of interaction, such as locomotion methods (i.e., methods for users to move through a virtual environment, such as a teleporting or artificial constant speed locomotion, etc.), which are transferred from video and computer gaming as 'new standards' [53,54]. In terms of adaptive user-oriented media to promote cognitive processing of spatial information, some experimental studies are dedicated to different user groups with the aim of deriving user-specific design rules, e.g., by developing routes along differently designed landmarks based on age-dependent memory abilities [55,56].

In summary, basic research on the use of immersive 3D landscapes within geoinformation science applications shows a clear emphasis on positivist understandings of VR landscapes based on associated widespread perspectives from cartography, geodesy, and spatial cognition research. A discussion and framing that allows for other established basic scientific theoretical perspectives on immersive 3D landscapes has-with the exception of a few initial approaches to constructivism [6]-been lacking so far. At this point, it seems worth taking a look at neighboring disciplines in the social sciences, such as human geography, which, in recent decades, have developed different theoretical perspectives on 
dealing with or constructing space that can be fruitfully applied to the study of (immersive) virtual environments.

\section{Current Theoretical Approaches in Spatial and Landscape Research}

The next section summarizes current, fundamental positions in spatial research (in particular theoretical landscape and cartography) discussions. A detailed consideration of the individual positions, which are sometimes categorized differently, can be found in a large number of publications (e.g., [8,9,15,57-66]). The presented approaches do not only refer to perspectives discussed in the English literature, but also take up approaches that have emerged in the German-speaking tradition and have proven to be fruitful for social science spatial research. We are convinced that they also have great potentials for the research on virtual environments.

\subsection{The Search for the 'Essence' of Spatial Entities: Essentialism}

The essentialist (from Latin, essentia = 'essence') assumes that "things possess necessary properties that constitute their essence" [67] (p. 15). Essentialist thinking dates back to ancient Greece and was cultivated especially in the Middle Ages [8]. With respect to space and landscapes, the central 'point of orientation' is to conceive spatial entities as 'wholes' characterized by 'essential' constituents and endowed with 'accidental' constituents. The 'essential' characteristics are considered to be those that are 'historically based' (historic landforms, farmhouses, etc.), while 'accidental' things are encountered only by chance (such as bungalows, neophytes, shopping malls, etc.) and are not specific to the space in question. A duality is often constructed between locality and regionality ('the typical') versus the 'global'. Specific preservation norms for certain (essential) materialities are often derived from essentialist spatial studies, as these have "an immutable intrinsic value and identity of their own" [62] (p. 97) while objects considered accidental are considered to be of inferior value, even harmful, and should be removed.

\subsection{Spaces as Objects and Object Constellations: Positivist Understandings}

While the essentialist understanding of the world reached the peak of its importance in the Middle Ages, positivism is connected with the modernization of science, in particular, and society, in general. Positivist thinking is associated with the Enlightenment and the rise of the natural sciences; it can be described as a variety of empiricism and is explicitly directed against the metaphysical [14]. Thus, the positivist understanding of world rejects an 'essence' of this world, here spatial entities, lying behind the manifestations of the material and immaterial (such as dialects) world. For positivist spatial researchers, these spatial units are a given object that can be accessed empirically (by measuring, weighing, and counting). Spaces are divided into different layers (which in today's geoinformation sciences are particularly concise, such as GIS layers, land use classifications of remote sensing, or thematic asset packs for 3D visualization with game engines), in which climate, vegetation, settlements, traffic routes, etc., are recorded in their location and extent. Individual objects can also be represented independently in their spatial dimensions (Figure 3).

According to Schultze [68] (p. 203) "real reality" spaces are defined as containers, which can be seen as 'filled' with different elements and which stand in an objectively definable relationship to one another. By recording their dimensions, characteristics, and location, they can be used in computer-aided modeling to forecast future spatial conditions on the basis of determined 'regularities' to support, for example, urban planning (Figure 4) [69]. 


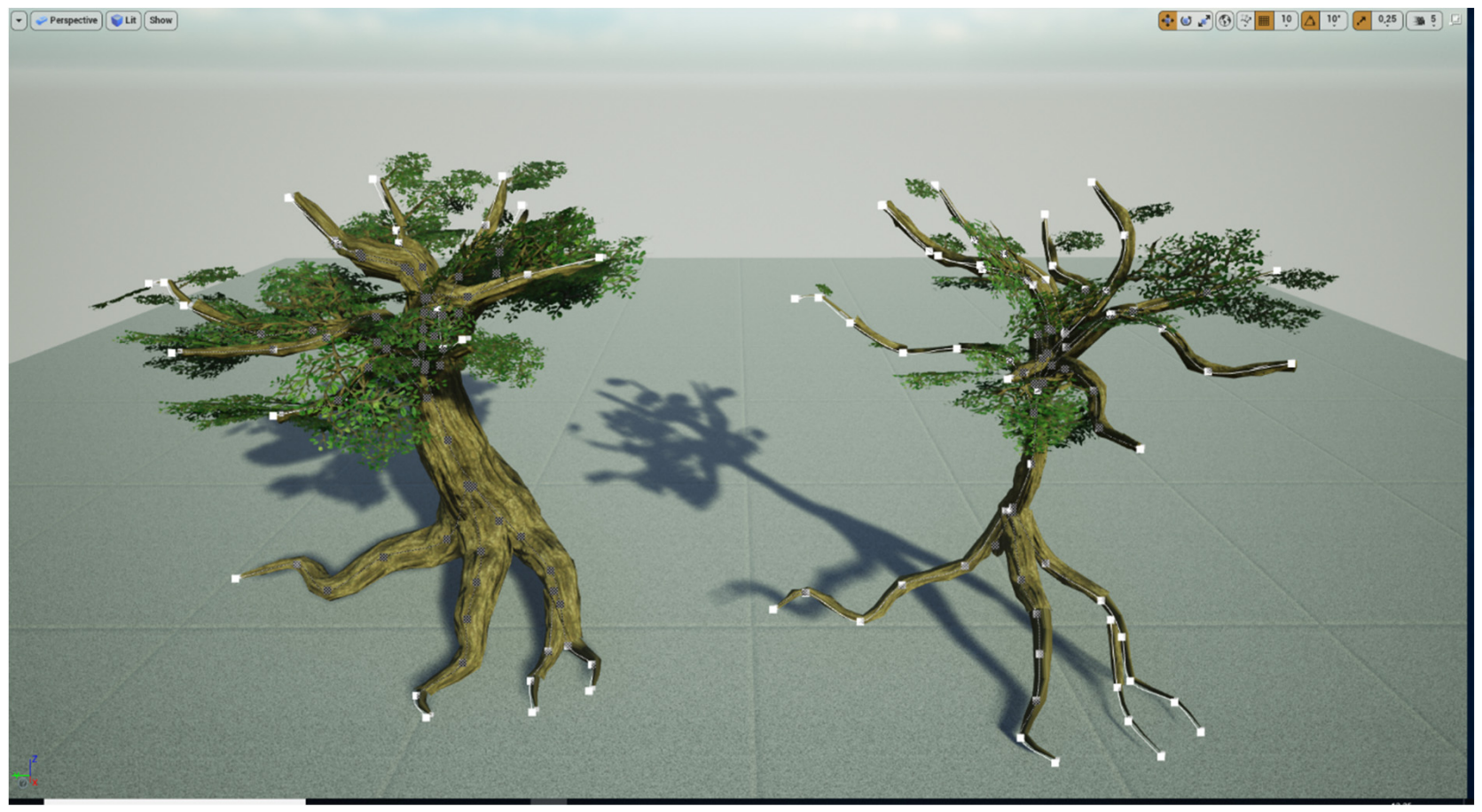

Figure 3. Example of an individual representation of trees with different properties as 3D objects (in Unreal Engine 4; own illustration by Dennis Edler and Timo Wiedenlübbert).

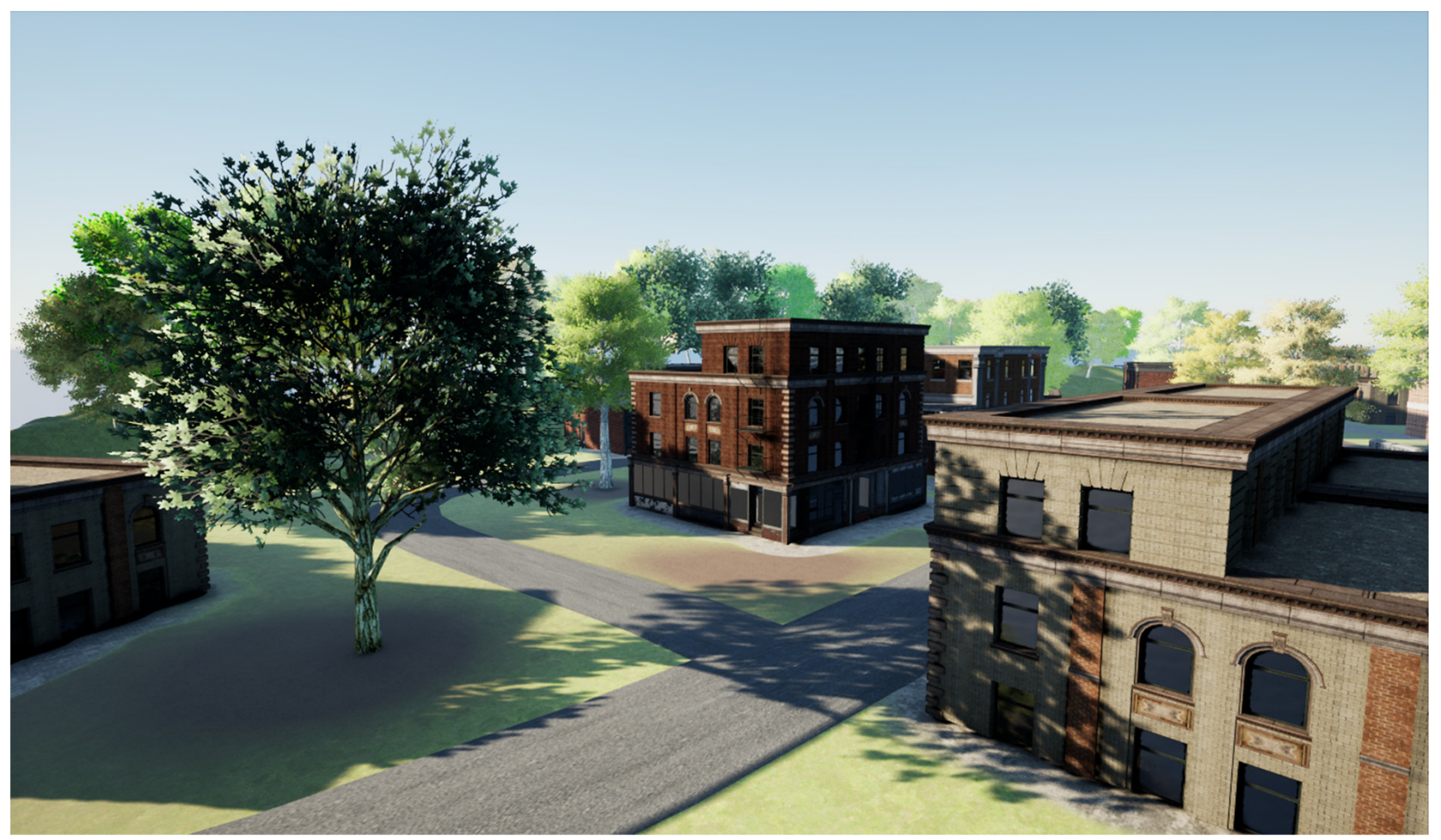

Figure 4. Example of an immersive large-scale planning scenario in a settlement (including streets, buildings, vegetation and shadows; own illustration by Dennis Edler and Timo Wiedenlübbert).

Positivistic spatial research, on the one hand, aims to describe states and analyze interrelationships for a world considered to be 'really existing,' but on the other hand, it does this by means of prognoses and scenarios. In comparison to an essentialist approach, the formulation of normative values is alien to it. 


\subsection{Spaces as Social Constructions-Constructivist Approaches}

Constructivist approaches have emerged in the social sciences since the mid-20th century and are directed in particular against the positivist notion that the social world can be explained by quantitative empirical methods [8]. In the last decades different constructivist approaches have been developed in spatial research in general, and in landscape research in particular. The constructivist approach commonly has a constitutive level of 'space', 'region' or 'landscape' not found in the material world, but in the social. 'Landscape' thus emerges through a synthesizing projection of socially preformed interpretations and evaluations of physical spaces [70]. The different constructivist theories have different foci. The social constructivist perspective focuses on how knowledge, interpretations, and evaluations of landscape emerge socially; how these are conveyed to the individual through the process of socialization and are internalized by the individual; in which form material spaces are symbolically charged (e.g., such as the frontier in the USA, forests in Germany, etc.); and the repercussions this charge has on the individual and society [71-74]. Following the Systems Theory of Niklas Luhmann [75], the radical constructivist perspective focuses on the way in which social subsystems (such as politics, economy, science, etc.) construct spatial units in different ways, for example as a means of earning money (in the economic subsystem), generating knowledge (in the scientific subsystem), or gaining power (in the political subsystem) [76-78]. From the perspective of Discourse Theory, mechanisms of negotiating interpretations of the world are brought into focus. 'Discourse' is understood less as an exchange of arguments than as a complex network of verbal and non-verbal communication, social conditions, and consequences $[79,80]$. Even though different traditions of Discourse Theory research on space have developed (following Michel Foucault [81], Jürgen Habermas [82] and Laclau and Mouffe [83]), the connecting point of interest is the power of defining of and about spaces. For instance, it is investigated which different discourses exist about landscape (e.g., as 'historically grown' vs. 'modern') and how these different discourses strive for hegemony in order to marginalize alternative discourses (see, e.g., [84-86]).

\subsection{After the Split of Subject and Object: More-than-Representational Theories}

The family of more-than-representational approaches was developed around the turn of the millennium in critical confrontation with, but also by taking up central statements of, constructivism. The revival of Phenomenology, from which social constructivism had developed, also falls into this period. Both positivist and constructivist understandings of the landscape assume a structuring of the world through social consciousness and the external world of objects (although constructivist approaches vary in intensity since social constructivism, for example, has phenomenological roots that also link individual people to objects). More-than-representational Theories $[87,88]$ is a collective name for approaches that seek to resolve this dichotomy. In Phenomenology, 'places' and 'spaces' come into focus as 'phenomena', i.e., they are understood as entities, as things and events that present themselves to the world [69] and which deal with the individual experience of places and spaces $[69,88,89]$. By focusing on the individual experience, the phenomenological researcher of places and spaces becomes the narrator of his experiences of a space [90]. Much more abstract is the Actor-Network-Theory (ANT) [91-93] which places social, technical, and natural entities and factors on an equal footing. These are treated by the "actor-network theory not as explanans, but as explananda" [94] (p. 188). Research that uses ANT uses its own terminology because classical scientific language is too entrenched in representational thought structures $[95,96]$. At the center of the ANT's concern with 'world' are networks resulting from the relations of animate and inanimate elements of space that have become 'actants'. Finally, the Assemblage Theory, similar to constructivism, integrates materialities into its theoretical framework by dealing with the question of how these materialities obtain social relevance-in a process of ordering matter around a body, an assemblage thereby forms as a constellation of imaginative co-occurring articulations between countless heterogeneous elements [97]. 


\subsection{Power and Space: Interpretations from Critical, Conflict-Theoretical and Framing-Theoretical Perspectives}

The question of social power relations and their spatial effects is addressed by all approaches that attribute a central importance to social processes in the production of space (i.e., with the exception of the positivist approach). In the following, we outline three approaches that place the question of power at the center of their considerations: critical perspectives (following Marx or Bourdieu), conflict theory (following Dahrendorf), and the framing approach.

Spatial studies, going back to Marx, are concerned with the unequal distribution of power in relation to space, and also often with questions of 'overcoming' unequal distributions of power [98-102]. This tradition of critical social research is closely linked to the Institute for Social Research founded in Frankfurt am Main in the mid-1920s. Central to this is the notion of the 'duplicity' [103] of spatial structures, for example, constructivist (landscape as a power-determined idea) versus positivist (landscape as a power-determined physical space). The central object of critique is the 'capitalist logic of spatial utilization' [104]. The dominance of economic calculation over alternative spatial claims, such as those arising from politics or community, leads to a 'commodification of spaces.' Additionally, the continued reproduction of unequal power relations is propagated by the fact that existing spatial structures are considered 'normal' and are not critically questioned. This also brings processes of spatial and landscape socialization into critique, because this has not only led to a domination of nature and the environment, but also to the "defamation of nature in man" [105] (p. 61) in that the latter has distanced himself from his original needs as provided by his surroundings. As a spatial-related medium of perpetuating unequal power relations, the representation of the world in maps has been critically examined in past decades, because they are understood less as depictions of something given than as (conscious or unconscious) attempts to perpetuate perceptions in the sense of perpetuating a capitalist social system [106]. In addition, or as an alternative to a Marxist approach, the sociology of Pierre Bourdieu [107] can be applied to the discussion of what significance standards of taste have in the design and use of physical spaces, how such 'aesthetic standards' are formed and by which parts of society, how they are socially disseminated, and how they materialize [108]. Bourdieu's perspective (starting at the turn of the 1960s to the 1970s) expands the classical perspective of critical research, which is strongly focused on economic relations, in the Marxist tradition, and the entanglements of economic capital with social capital (i.e., resilient social networks) and cultural capital (e.g., educational titles, knowledge, culturally charged objects; $[109,110])$.

In contrast to Marxist approaches, Ralf Dahrendorf's conflict theory is not based on the goal of fundamentally changing society, but on allowing society itself to change through the struggle for the most suitable answers to concrete challenges. This struggle is thus constitutively bound to conflicts [111-115]. Dahrendorf's conflict theory received professional attention since the early 1960s and continued to be developed until Dahrendorf's death in 2009. Conflict unfolds in three principal steps: the structural starting position, the awareness of this starting position, and the open expression of conflict combined with the tendency of conflicts to lead to a dichotomous division of society. Conflicts can, however, become productive for society, provided they are regulated, not suppressed, or an attempt is made to resolve them (i.e., to eliminate the social causes of conflicts). Preconditions for a productive settlement are: the recognition of the differing perspectives as legitimate and valid; the reference of the settlement to the manifestations of the conflict, not to its causes; a high degree of organization of the conflict parties; and the observance of procedural rules which are unbiased and do not favor any side. In addition, the adjudication requires an authority (commonly the role of the state) to be able to decide on a settlement of the conflict in the event an agreement by the parties cannot be reached. In spatial research, conflict theory provides a framework for understanding the genesis of spatial conflicts (e.g., energy transition from carbon-based to renewables, the extraction of raw materials, 
etc.; [116-118]), but also gives suggestions for possible conflict resolution methods, apart from violent revolution.

The framing approach, essentially leading back to the publications of the sociologist Goffman [119] in the 1970s, can also be assigned to constructivist theories; in this case, however, we focus on its potential in the context of conflict resolution. Throughout the course of its development, the framing approach can be found in diverse disciplines such as the study of environmental conflicts, negotiation management, border research, political science, and media science, to name but a few [120-129]. The theory focuses on the analysis of how events or certain information/topics are embedded in social patterns, and how complex information is cognitively interpreted and communicatively processed through these social patterns in an effort to reduce the complexity of the issue. According to Goffman [119], 'frames' represent so-called 'schemata of interpretation,' which ascribes meaning to otherwise meaningless events. Shmueli [121] (p. 2049) points out that the term 'frame' can be used both as a noun and as a verb: as a noun, 'frame' denotes "the boundary within which a picture is displayed and set apart from the background; it plays a filtering role in perception, interpretation and understanding of specific situation." As the verb '(to) frame', however, the term refers "to the crafting of a frame, whether deliberately or not, during communication" [121] (p. 2049). Depending on the context, conscious or even unconscious framing can be used "to conceptualize and interpret, or manipulate and persuade" [121] (p. 2049) and thus seek a degree of control over how something is communicated and perceived [130]. Reframing, on the other hand, deliberately aims to change the perceptual frame of the other person, for example, to promote joint decisionmaking in conflict situations $[120,130,131]$.

\subsection{The Challenge of the Ambiguity of Spaces-The Neo-Pragmatic Consequence}

Neopragmatism emerged around the turn of the millennium in response to an increasing differentiation of theoretical perspectives and methodological derivations from them with an exclusivist claim to validity. Instead of emphasizing the divisive, it seeks complimentarity. The consequence is that up to this point, we have outlined the main theoretical approaches to spatial research. In doing so, the diversity of current perspectives as well as the limitations of framing certain topics and processes becomes clear. At the same time, the different approaches partly show competing interpretations. Accordingly, doubts arise as to whether there is, or even can be, only one legitimate theoretical perspective for 'space' in general, or 'place', 'region', 'landscape', etc. Especially in the context of an inter- and transdisciplinary approach to landscape, such a theoretically puristic claim seems inopportune. On the one hand, there are research discipline preferences for a theory (scientific spatial research is almost exclusively done in a positivist tradition and could hardly be framed in a radical constructivist perspective even on the object level). On the other hand, in the practical handling of 'space' (whether in planning, politics or garden design) certain approaches (brought forward exclusively) are not very connectable ([132]; in a thought experiment, a garden design could be designed from a discourse-theoretical perspective). In this respect, a neo-pragmatic approach to the theoretical framing of research on spaces certainly seems to be an alternative. Based on the objective of the spatial research, in a neo-pragmatic approach, different theoretical and methodological approaches, data, and researchers are triangulated to investigate the addressed research questions in order to achieve a better understanding of the object of investigation, since mono-theoretical perspectives or mono-methodological approaches tend to be one-sided when dealing with practice-related questions in particular [133-135]; the theories suitable for individual subquestions are then justified, which, however, presupposes a comparison and weighting of different theoretical approaches [136-138].

\section{The Potentials of Theoretical Framing for a More Comprehensive Understanding of Virtual Realities}

In this section, we address the question of whether, how, and in which form the theoretical approaches to space and landscape presented in the preceding sections can be 
utilized as a theoretical framework for VR research. In anticipation of the concluding result of our comparisons, all of the theoretical approaches presented are suitable for framing aspects of VR landscapes and spaces, with the exception of essentialism. Our considerations on the suitability of the basic theoretical position for VR research are divided into three levels (see also Figure 5):

1. The level of technical foundation, i.e., geospatial data as well as hardware and software, which is the inescapable basis for the representation of virtual worlds.

2. The level of sophistication of the virtual worlds, i.e., the representation of virtual spaces and landscapes themselves, including the processing of digital geodata.

3. The level of research in relation to the other two levels, specifically:

(a) how virtually generated spaces and landscapes can be used as a medium of research, and

(b) how they can become the object of research from a socio-theoretical and ideological perspective.

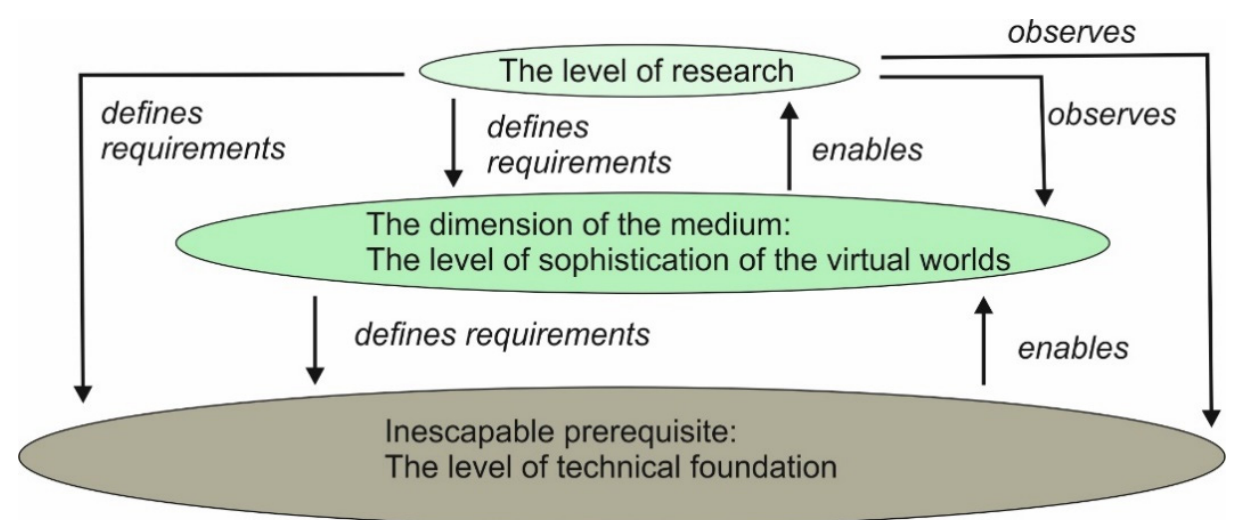

Figure 5. The different levels of VR research (own representation).

Essentialist landscape theory does not provide a suitable framework in that virtually produced spaces and landscapes contradict the normative content of essentialism according to an 'essence' that has evolved from a reciprocal formation of culture and nature. This is for several reasons: VR lacks the natural component, it is a pure product of culture, and VR is accidental because its elements are highly contingent on, and not strongly determined by, the regionally specific mutual shaping of nature and culture used in the program. Nor can VR-as a result of global production-develop regional specificity. Even if the regionally specific is represented, it remains with the accidental representation of the region selected. This is not an expression of an 'essence' of a (VR) landscape, but-from an essentialist perspective - an appearance that distracts from dealing with the 'essence' of 'real' landscapes. In terms of the three analytical levels formulated above, this means that since both the technical foundations and the VR landscapes and spaces are rejected as accidental from a theoretical perspective (level $3 b$ ), they cannot (and in the sense of deontic modal logic, must not) be used as a means of research (level 3a).

If VR-related research seems constitutively almost impossible in essentialist theoretical framing, VR research is already established under (mostly implicit) positivist framing. This framing can be divided into the three levels described above. The first level refers to the production of the technical foundations for VR, both in terms of hardware and software development $[13,19,23]$. The second level is found in the content of VR, for instance when (mostly thematic cartographic) applications are transferred to immersive VR and further developed. On the one hand, this can be related to the continuation of traditional signature language, on the other hand, it can also be related to further development of multimedia and animated symbols [38]. The virtual recreation of historical spatial conditions (e.g., of cities) that is as 'true to the original' as possible is also to be located on this level [42,139-141]. The third level refers to research on, or by means of, VR as a medium 
of inquiry in the continuation of positivist science, especially in the tradition of cognitive and experimental psychological designs and in questions of spatial cognition research and cognitive cartography $[22,54,142]$. VR thus becomes an interactive and immersive medium for measuring behavioral data on specific stimuli presented in VR, such as distance estimates or memory performance $[22,56,143]$, by offering the possibility of tapping into basic measures of spatial cognition research and feeding back into the user-oriented design of appropriate media [47-49]. These positivistically framed methods are complemented by the quantitative survey, the results of which—as well as other results—can be evaluated through tests and estimation statistics. Thus, a positivist approach ultimately has great potential for scholarly engagement within all three levels of VR research.

Social constructivism focuses on the relationship of the individual with society, and less on the possibilities and limitations of the technological world. In this respect, its potential for VR-related spatial and landscape research lies less at level 1 formulated above, and more specifically at levels $3 \mathrm{a}$ and $3 \mathrm{~b}$ with recourse to level 2 . In this context, several questions arise [6]:

- Which social landscape stereotypes can be derived from published VR landscapes? In this case, VR landscapes themselves become the object of research. Qualitative interviews or qualitative media content analyses (e.g., through evaluations of discussion forums on VR landscapes) can broaden the perspective by examining how spaces/landscapes are socially constructed, what symbolic attributions exist, and how interpretations and values are socially negotiated.

- VR landscape can also become a consciously designed medium for social constructivist framed landscape research. VR serves here as an idealized research laboratory or landscape construction, so VR landscapes tested individually by people can be examined for their utopian, dystopian, and stereotypical content. Additionally, the meaning of selected sensory perceptions can be examined, for example in terms of lighting (light/dark, shaded, types of lighting, etc.), but also by combining optical and acoustic stimuli [144].

More strongly related to level $3 b$, questions can be addressed in a social constructivist context about how knowledge about VR is generated and passed on in society; which socialization and innovation aspects exist; how VR is becoming part of (landscape) socialization; which changes are occurring with respect to landscape socialization [145-147] due to its (partial) virtualization; but also, how can the individual change spaces and spatial concepts without much physical effort?

Discourse Theory, which focuses on mechanisms and effects of the pursuit of hegemonic discourses, can connect to these questions. It has particular potential on the $3 \mathrm{~b}$ level of VR landscape research by asking how normality of landscape is defined by VR, deviations of hegemonic discourse, what counts as VR landscape, and to what extent discursive closures occur in relation to the desirability of VR landscape representations. Discussions around the enforcement of hardware and software standards can also be framed from this perspective, as well as strong, morally charged discourses. Examples of these moral debates include suitability of certain objects, such as first-person VR representation of shooters and their effects on the non-VR world, but also the extent to which intensive immersion in VR may diminish social skills and physical performance (on morality and landscape, see [148-150]). This is where the potential of an autopoietic-systems-theoretical framing may come in-through the challenge of moralizing technical and factual issues, with the consequence of generating mutual moral devaluations on the basis of different moral systems [151,152]. It is also possible to use this theoretical perspective to frame how different sub-systemic interpretations and evaluations of virtual spaces/landscapes are made. Simulations on level 2 can thus be used as a basis of how those virtual representations are interpreted and evaluated differently from an economic (e.g., agriculture, tourism) or political perspective.

As to more-than-representational theories, a complementary suitability of Phenomenology to the social constructivist perspective can be established for VR research. Accordingly, 
it is investigated (from the level 3a perspective) how the individual experiences virtually generated landscapes in particular, and spaces in general, rather than which (more cognitive) social (often) stereotypical patterns of interpretation and evaluation are formed. Thus, the method of phenomenological walks $[90,136,153]$ can also be applied to virtual spaces and landscapes, with particular potential existing in multisensory approaches to increase the individual immersion experience $[37,144]$. Non-standardized qualitative interviews offer a methodological approach here. The other more-than-representational theories, i.e., Assemblage Theory and Actor-Network-Theory, show specific potentials in the hybrid forms of the material and virtual worlds in the context of augmented reality (AR), as the dissolution of the dichotomous construction of world is particularly evident here [154]. With regard to framing and AR, however, a level 3a perspective can also be established when investigating what symbolic meaning represented objects have for people, because these object representations can be consciously placed within the AR.

Critical theory, in a neo-Marxist interpretation, can be related especially to level 3b, but also in parts to level 3a. VR can be interpreted overall as an element of escapism. It escapes from the world shaped by 'capitalist relations of domination,' in which man is alienated from his 'inner and outer nature' $[105,155]$, the latter being a state to which VR immersion contributes. In doing so, VR integrates people into capitalist logic in two ways: on the one hand, it requires the financial means to procure and operate technical equipment; on the other hand, it actualizes traditional (stereotypical) notions of space and landscape that are expressions of unequal distribution of power. The use of VR in game context is dominated by the glorification of violence, militarism, racism, sexism, an anti-collectivist individualism (particularly evident in ego-shooters), imperialism, and colonialism, especially in strategy games such as Civilization or Age of Empires [156-159]. The approach to VR, which is very clearly reduced to economic references [160], can be broadened on the basis of Pierre Bourdieu's sociology, for instance by investigating which endowment of symbolic capital-beyond economic capital—is necessary to gain access to VR. In the form of incorporated cultural capital, for example, this includes which effects the use of VR has on the availability of social capital, but also how incorporated capital can be generated through the use of VR (for instance through its use in educational contexts), although this investigation is also possible from a non-critical theory perspective and social constructivist theoretical framing, for instance [161,162]. Furthermore, from the perspective of a Bourdieu-based critical theory VR research, the question can be posed how aesthetic preferences are inscribed in virtual landscapes, and how they (can) contribute to the transformation from 'legitimate' to 'subordinate' preference, which can be quite milieu-specific.

From the perspective of conflict theory (in the tradition of Ralf Dahrendorf), it is possible to access the other levels from level $3 b$, i.e., it is possible to examine how conflicts about the setting of technical standards were or are regulated, but it is also possible to examine which forms - here especially in games - of dealing with conflicts exist (in this case, conflicts are often constitutive for game action). An access also arises on level 3a through VR simulation by analyzing which changes of landscape/space are interpreted and evaluated, and how this affects conflict courses. Here we find a transitional point to explore the potential of the framing theory, which is less macro-sociologically conceived. The framing approach can also contribute to cooperative solutions in the context of spatial conflicts with technical innovations of VR, especially in mediation or participation procedures. In this case, the potential associated with reframing could be exploited even more than analog formats allow, in that the simulation of conflicts can be meaningfully expanded through the hybrid materiality of VR, for example in the testing of different possibilities of conflict resolution in the form of role-playing, simulation, etc.

The neo-pragmatic approach offers a framework for a well-founded triangulation of theories, methods, data, and researchers, also with regard to VR research. If not only isolated facts, interpretations, evaluations, experiences, etc., are to be investigated, but if the topic of VR is broader, such a combination is appropriate. Since the social science 
approach to VR usually deals with the investigation of individual approaches and their generalizability, social constructivism and Phenomenology as complementary theories (also with regard to their genesis), as two sides of the same coin, form a methodological core which can be extended and underpinned by further theoretical approaches-in accordance with the respective research question (Figure 6). Examined collectively, an investigation on conflicts about the planned construction of a wind farm (in material space) could be operationalized by the design of a VR environment (on level 3a); individual experience and the actualization of societal patterns of interpretation and evaluation could be framed through Phenomenology and social constructivism, while anticipated societal conflicts can be derived from conflict theory, and concrete approaches to conflict management could be made through framing theory. However, a critical theory perspective (from Bourdieu) could also be applied, for example by examining standards of preference with regard to societal class. The figure also shows that essentialism is incommensurable with the theoretical framework of neo-pragmatic VR research; after all, from an essentialist perspective VR must be something accidental, which from an essentialist perspective must be normatively rejected. In this respect, essentialism is also placed outside the circle in Figure 6.

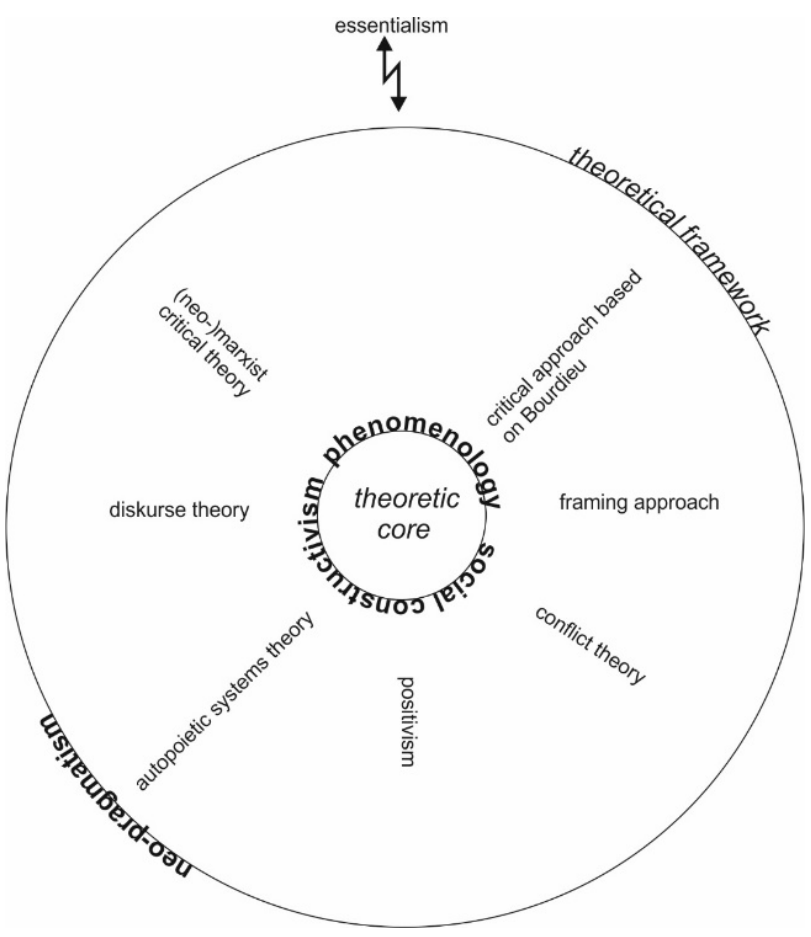

Figure 6. The different landscape-theoretical approaches between theoretical framework and theoretical core. The inner ring symbolizes the theoretical core formed by Phenomenology and social constructivism, which ultimately represent two sides of the same coin, one side defining the relationship of the individual to the non-social environment (Phenomenology), the other side (social constructivism) defining the relationship of the individual to the social environment. The other theories complement this core. The outer circle defines the neo-pragmatic framework, which includes the theories that can be meaningfully integrated. Essentialism stands outside the circle, rejecting VR as accidental (own representation).

\section{Conclusions}

The growing field of research on immersive virtual environments requires a theoretical framework if it is understood synthetically. Given the complexity of the subject as well as the empirical approaches to it, a unified theoretical framework in the sense of a unified 'theory of VR' is not only unlikely, but also not necessarily desirable, since it would inevitably leave partial aspects unaddressed. If immersive VR is to be framed more comprehensively in theoretical terms, a meta-theoretical approach in the sense of a neo- 
pragmatic approach, which triangulates different theories of 'medium range' $[163,164]$ is suggested $[133,135,165]$. Our analysis offers numerous starting points for the theoretical classification of investigations on virtual realities, and thus possibilities for connecting to current discussions in the spatial sciences.

Referring to the theoretical approaches presented, different potentials and degrees of utilization (or exploitation) for VR research can be identified from a social science perspective. The extreme positions are occupied by the essentialist and the positivist perspectives. The positivist perspective has a high potential, and it is already widely exploited. The essentialist perspective has no conceptual suitability and thus offers no basis for exploitation. The middle-ground is dominated by the social constructivist and phenomenological perspectives; here, a very large potential is found (as shown, in the sense of a central perspective), although it has so far only been rudimentarily exploited. Discourse and radical constructivist perspectives have a very specialized scope in spatial research due to their meta-level conception. In this respect, they have potential in social science VR research, although this has hardly been exploited currently. Regarding the great potential of critical perspectives, an uneven degree of exploitation can be observed in favor of the neo-Marxist perspective (especially in terms of game research), while the approach by means of Bourdieu's sociology has not yet been elaborated. Conflict theory, in turn, shows potential for social science research, although detailed studies are pending in this regard, while empirical research results are available [166-169] which are open to theoretical classification by framing theory [170].

The presentation of theoretical perspectives (see overview in Table 1) is not exhaustive since it is limited to essential contemporary approaches of landscape-theoretical research. Also, as a result of the development of new theories, additional perspectives are always conceivable. Furthermore, depending on the question to be investigated and their justified contextualization with the theoretical approaches already used, theories of 'medium range' can be inserted into a neo-pragmatic framework. This, in turn, has great potential for the investigation of complex questions related to (immersive) VR, not exclusively in social sciences. It is a topic which is still waiting to be explored in detail.

Table 1. Overview of the different approaches discussed. The world reference used here in the second column goes back to Karl Popper. He understands world 1 as the material world [171,172], world 2 as the world of individual consciousness, and world 3 as the world of socially shared knowledge. The worlds are not structurally separated from each other, but connect, for example in books, which are part of world 1 and world 3 (own representation).

\begin{tabular}{|c|c|c|c|c|c|}
\hline & $\begin{array}{l}\text { World- } \\
\text { Relatedness }\end{array}$ & Understandings & Potentials & $\begin{array}{l}\text { Utilization } \\
\text { Rate }\end{array}$ & Exemplary Questions \\
\hline Essentialism & $\begin{array}{l}\text { World } 1,2 \text { and } 3 \text { as } \\
\text { a holistic whole }\end{array}$ & $\begin{array}{l}\text { Space as a unit } \\
\text { with a subjectively } \\
\text { ascertainable } \\
\text { essence core }\end{array}$ & $\begin{array}{l}\text { None, since it rejects } \\
\text { virtual worlds }\end{array}$ & - & \\
\hline Positivism & $\begin{array}{l}\text { Especially world 1, } \\
\text { but also world } 3\end{array}$ & $\begin{array}{l}\text { Spaces as } \\
\text { containers, filled } \\
\text { with certain } \\
\text { elements that can } \\
\text { be objectively } \\
\text { captured }\end{array}$ & $\begin{array}{l}\text { Describing states } \\
\text { and their } \\
\text { relationships to each } \\
\text { other; updating by } \\
\text { means of forecasts or } \\
\text { scenarios; providing } \\
\text { technical bases }\end{array}$ & $\begin{array}{l}\text { Highly } \\
\text { pronounced }\end{array}$ & $\begin{array}{l}\text { Questions concerning } \\
\text { location and extent of } \\
\text { climate, vegetation, } \\
\text { settlements, traffic } \\
\text { routes, etc.; furthermore, } \\
\text { spatial cognition } \\
\text { research, cognitive } \\
\text { cartography as well as } \\
\text { development of basic } \\
\text { dimensions and } \\
\text { user-oriented } \\
\text { construction of } \\
\text { media, etc. }\end{array}$ \\
\hline
\end{tabular}


Table 1. Cont.

\begin{tabular}{|c|c|c|}
\hline & $\begin{array}{l}\text { World- } \\
\text { Relatedness }\end{array}$ & Understandings \\
\hline $\begin{array}{l}\text { Social- } \\
\text { Constructivism }\end{array}$ & $\begin{array}{l}\text { Especially world } 2 \\
\text { and } 3 \text { and their } \\
\text { relations }\end{array}$ & $\begin{array}{l}\text { Constitutive level } \\
\text { of space not in } \\
\text { material world but } \\
\text { in social; focus on } \\
\text { knowledge, } \\
\text { interpretation and } \\
\text { evaluations and } \\
\text { their socialization }\end{array}$ \\
\hline
\end{tabular}

\section{Potentials}

Research of spatial evaluations and influencing factors

Utilization
Rate

Exemplary Questions

Formation of space-related stereotypes; symbolic attributions of spaces as well as questions about the significance of a wide variety of influences such as daytime/nighttime, weather, seasons etc. in the evaluation and interpretation of space, etc.

Questions about sub-systemically

Constitutive level of space not in

RadicalFocus on world 3 material world but in social; focus on social subsystems
Exploration of space as a medium of different social subsystems
Hardly to slightly pronounced different ways of constructing spatial entities, generations of reciprocal moral devaluations, etc.

Constitutive level of space not in material world but

Discourse Theory

Focus on world 3

Phenomenology

Especially world 1 and 2 and their relations in social; focus on mechanisms of negotiation of spatial interpretations.
'Phenomena' understood as entities, as things and events that present themselves
Questions about the power of definition of

Mechanisms of negotiating interpretations of space

Hardly to slightly pronounced and about spaces and discursive closures, possibly considering consequences for World 1. to the world as space

Spaces as networks

Cannot be

ANT classified because everything is resolved in networks resulting from the relations of the animate and inanimate elements (actants) of space

Constitutive leve of space in the social with a stronger integration of its materialities
Focus world 1 and 3 , but also

Assemblage reference to world 2
Space as an object of economic calculation

World 1 and 3 , versus other spatial claims

Critical Theory
Bourdieu also with stronger focus on world 2 entanglements of economic capital with social and cultural capital in Bourdieu
Research on space as individual experience and experience slightly pronounced

Research on the relations of equal actants of social technical and natural entities/factors Not to hardly
pronounced
Research on the emergence of social relevance of spaces
Not to hardly pronounced
Questions about factors of individual spatial experience and experience of space
Questions about training to networks and the relations of the actants as well as influencing variables
Question of obtaining social relevance of legacy industries, tourism destinations, etc.
Question of mapping spaces as (conscious or unconscious) attempts to perpetuate of existing spatial power structures to prevent the reproduction of unequal spatial power relations and, if necessary, their reversal
Hardly to slightly pronounced perceptions in terms of a capitalist social system, also: alienation and escapism; with Bourdieu, importance of aesthetic taste standards in the design and use of physical spaces 
Table 1. Cont.

\begin{tabular}{|c|c|c|c|c|c|}
\hline & $\begin{array}{l}\text { World- } \\
\text { Relatedness }\end{array}$ & Understandings & Potentials & $\begin{array}{l}\text { Utilization } \\
\text { Rate }\end{array}$ & Exemplary Questions \\
\hline Conflict Theory & $\begin{array}{l}\text { World } 2 \text { and } 3 \text { with } \\
\text { references to } \\
\text { world } 1\end{array}$ & $\begin{array}{l}\text { Conflicts over } \\
\text { space as a social } \\
\text { normality }\end{array}$ & $\begin{array}{l}\text { Understanding of } \\
\text { the genesis of spatial } \\
\text { conflicts as well as } \\
\text { indications for a } \\
\text { possible regulation } \\
\text { of conflicts }\end{array}$ & $\begin{array}{l}\text { Hardly to } \\
\text { slightly } \\
\text { pronounced }\end{array}$ & $\begin{array}{l}\text { Spatial conflict } \\
\text { regulation, governance }\end{array}$ \\
\hline Framing & $\begin{array}{l}\text { World } 2 \text { and } 3 \text { with } \\
\text { references to world } \\
1 \text {, stronger } \\
\text { importance of } \\
\text { world } 2\end{array}$ & $\begin{array}{l}\text { Constitutive level } \\
\text { of space in the } \\
\text { social with focus } \\
\text { on embedding } \\
\text { interpretive } \\
\text { patterns to spaces } \\
\text { in specific } \\
\text { situations }\end{array}$ & $\begin{array}{l}\text { Exploring the } \\
\text { filtering role of } \\
\text { frames in the } \\
\text { perception, } \\
\text { interpretation, and } \\
\text { understanding of a } \\
\text { given situation }\end{array}$ & $\begin{array}{l}\text { Low to } \\
\text { medium } \\
\text { pronounced }\end{array}$ & $\begin{array}{l}\text { Negotiation situations, } \\
\text { decision-making, } \\
\text { conflict resolution, } \\
\text { governance, mediation, } \\
\text { participatory processes, } \\
\text { role-playing }\end{array}$ \\
\hline $\begin{array}{l}\text { Neo- } \\
\text { Pragmatism }\end{array}$ & $\begin{array}{l}\text { All three worlds } \\
\text { with their } \\
\text { references }\end{array}$ & $\begin{array}{l}\text { Space as } \\
\text { triangulation of } \\
\text { different } \\
\text { understandings }\end{array}$ & $\begin{array}{l}\text { Practical handling of } \\
\text { spatial questions, jus- } \\
\text { tified triangulation } \\
\text { of methods } \\
\text { and theories } \\
\text { depending on the } \\
\text { spatial question }\end{array}$ & $\begin{array}{l}\text { Hardly to } \\
\text { slightly } \\
\text { pronounced }\end{array}$ & $\begin{array}{l}\text { Issues in governance, } \\
\text { planning, energy } \\
\text { transition, landscape as } \\
\text { a special case of } \\
\text { space etc. }\end{array}$ \\
\hline
\end{tabular}

Source: Own compilation and presentation.

Author Contributions: Conceptualization, Olaf Kühne, Dennis Edler and Corinna Jenal; Writing-Original draft preparation, Olaf Kühne, Dennis Edler and Corinna Jenal; Writing-review and editing, Olaf Kühne, Dennis Edler and Corinna Jenal; Visualization, Olaf Kühne, Dennis Edler and Corinna Jenal. All authors have read and agreed to the published version of the manuscript.

Funding: This research received no external funding.

Institutional Review Board Statement: Not applicable.

Informed Consent Statement: Not applicable.

Data Availability Statement: The study does not report any data.

Conflicts of Interest: The authors declare no conflict of interest.

\section{References}

1. Vetter, M. Technical Potentials for the Visualization in Virtual Reality. In Modern Approaches to the Visualization of Landscapes; Edler, D., Jenal, C., Kühne, O., Eds.; Springer: Wiesbaden, Germany, 2020; pp. 307-317.

2. Prisille, C.; Ellerbrake, M. Virtual Reality (VR) and Geography Education: Potentials of $360^{\circ}$ 'Experiences' in Secondary Schools. In Modern Approaches to the Visualization of Landscapes; Edler, D., Jenal, C., Kühne, O., Eds.; Springer: Wiesbaden, Germany, 2020; pp. 321-332.

3. Braun, H.; Friess, R. Empirische Zugänge zur Virtual Reality: Heterogenes Netzwerk, Diskurs und Wahrnehmungsform. In Handbuch Virtualität; Kasprowicz, D., Rieger, S., Eds.; Springer: Wiesbaden, Germany, 2019; pp. 1-21.

4. Crang, M.; Crang, P.; May, J. (Eds.) Virtual Geographies: Bodies, Space and Relations; Routledge: London, UK; New York, NY, USA, 1999.

5. Kühne, O.; Jenal, C. The Threefold 'Landscape Dynamics-Basic Considerations, Conflicts and Potentials of Virtual Landscape Research. In Modern Approaches to the Visualization of Landscapes; Edler, D., Jenal, C., Kühne, O., Eds.; Springer: Wiesbaden, Germany, 2020; pp. 389-402.

6. Edler, D.; Kühne, O.; Jenal, C.; Vetter, M.; Dickmann, F. Potenziale der Raumvisualisierung in Virtual Reality (VR) für die sozialkonstruktivistische Landschaftsforschung. KN J. Cartogr. Geogr. Inf. 2018, 68, 245-254. [CrossRef]

7. Lange, E. The limits of realism: Perceptions of virtual landscapes. Landsc. Urban Plan. 2001, 54, 163-182. [CrossRef]

8. Kühne, O. Landscape Theories: A Brief Introduction; Springer: Wiesbaden, Germany, 2019.

9. Wylie, J. Landscape; Routledge: Abingdon, UK, 2007.

10. Taylor, D.R.F. A Conceptual Basis for Cartography: New Directions for the Information Era. Cartogr. J. 1991, $28,213-216$. [CrossRef]

11. Fisher, P.; Unwin, D. Virtual Reality in Geography; Taylor \& Francis: London, UK, 2001. 
12. Çöltekin, A.; Lochhead, I.; Madden, M.; Christophe, S.; Devaux, A.; Pettit, C.; Lock, O.; Shukla, S.; Herman, L.; Stachoň, Z.; et al. Extended Reality in Spatial Sciences: A Review of Research Challenges and Future Directions. ISPRS Int. J. Geo Inf. $2020,9,439$. [CrossRef]

13. Hruby, F.; Ressl, R.; de la Borbolla Valle, G. Geovisualization with immersive virtual environments in theory and practice. Int. J. Digit. Earth 2019, 12, 123-136. [CrossRef]

14. Kühne, O.; Berr, K. Wissenschaft, Raum, Gesellschaft: Eine Einführung zur sozialen Erzeugung von Wissen; Springer: Wiesbaden, Germany, 2021.

15. Poser, H. Wissenschaftstheorie: Eine Philosophische Einführung; Philipp Reclam jun.: Stuttgart, Germany, 2012.

16. Dewey, J. Logik: Die Theorie der Forschung; Suhrkamp: Frankfurt am Main, Germany, 2016.

17. Kuhn, T.S. Die Struktur Wissenschaftlicher Revolutionen; Suhrkamp: Frankfurt am Main, Germany, 1976.

18. Hruby, F.; Sánchez, L.F.Á.; Ressl, R.; Escobar-Briones, E.G. An Empirical Study on Spatial Presence in Immersive GeoEnvironments. PFG J. Photogramm. Remote. Sens. Geoinf. Sci. 2020, 88, 155-163. [CrossRef]

19. Lütjens, M.; Kersten, T.; Dorschel, B.; Tschirschwitz, F. Virtual Reality in Cartography: Immersive 3D Visualization of the Arctic Clyde Inlet (Canada) Using Digital Elevation Models and Bathymetric Data. MTI 2019, 3, 9. [CrossRef]

20. Walmsley, A.; Kersten, T.P. Low-cost Development of an Interactive, Immersive Virtual Reality Experience of the Historic City Model Stade 1620. Int. Arch. Photogramm. Remote. Sens. Spat. Inf. Sci. 2019, 42, 405-411. [CrossRef]

21. Schmohl, S.; Tutzauer, P.; Haala, N. Stuttgart City Walk: A Case Study on Visualizing Textured DSM Meshes for the General Public Using Virtual Reality. PFG J. Photogramm. Remote. Sens. Geoinf. Sci. 2020, 88, 147-154. [CrossRef]

22. Keil, J.; Edler, D.; Schmitt, T.; Dickmann, F. Creating Immersive Virtual Environments Based on Open Geospatial Data and Game Engines. KN J. Cartogr. Geogr. Inf. 2021, 71, 1-13. [CrossRef]

23. Edler, D.; Husar, A.; Keil, J.; Vetter, M.; Dickmann, F. Virtual Reality (VR) and Open Source Software: A Workflow for Constructing an Interactive Cartographic VR Environment to Explore Urban Landscapes. KN J. Cartogr. Geogr. Inf. 2018, 68, 5-13. [CrossRef]

24. Puyana-Romero, V.; Lopez-Segura, L.S.; Maffei, L.; Hernández-Molina, R.; Masullo, M. Interactive Soundscapes: $360^{\circ}$-Video Based Immersive Virtual Reality in a Tool for the Participatory Acoustic Environment Evaluation of Urban Areas. Acta Acust. United Acust. 2017, 103, 574-588. [CrossRef]

25. Mancini, M.; Cherubino, P.; Cartocci, G.; Martinez, A.; Borghini, G.; Guastamacchia, E.; Di Flumeri, G.; Rossi, D.; Modica, E.; Menicocci, S.; et al. Forefront Users' Experience Evaluation by Employing Together Virtual Reality and Electroencephalography: A Case Study on Cognitive Effects of Scents. Brain Sci. 2021, 11, 256. [CrossRef]

26. Chen, M.; Lin, H.; Kolditz, O.; Chen, C. Developing dynamic virtual geographic environments (VGEs) for geographic research Environ. Earth Sci. 2015, 74, 6975-6980. [CrossRef]

27. Virtanen, J.-P.; Hyyppä, H.; Kämäräinen, A.; Hollström, T.; Vastaranta, M.; Hyyppä, J. Intelligent Open Data 3D Maps in a Collaborative Virtual World. ISPRS Int. J. Geo Inf. 2015, 4, 837-857. [CrossRef]

28. Wen, Y.; Chen, M.; Lu, G.; Lin, H.; He, L.; Yue, S. Prototyping an open environment for sharing geographical analysis models on cloud computing platform. Int. J. Digit. Earth 2013, 6, 356-382. [CrossRef]

29. Lin, H.; Gong, J. Exploring Virtual Geographic Environments. Geogr. Inf. Sci. 2001, 7, 1-7. [CrossRef]

30. Zhu, J.; Yin, L.; Wang, J.; Zhang, H.; Hu, Y.; Liu, Z. Dam-break flood routing simulation and scale effect analysis based on virtual geographic environment. IEEE J. Sel. Top. Appl. Earth Obs. Remote. Sens. 2015, 8, 105-113. [CrossRef]

31. Torrens, P.M.; McDaniel, A.W. Modeling Geographic Behavior in Riotous Crowds. Ann. Assoc. Am. Geogr. 2013, 103, 20-46. [CrossRef]

32. Torrens, P.M. High-fidelity behaviours for model people on model streetscapes. Annals of GIS 2014, 20, 139-157. [CrossRef]

33. Jamei, E.; Mortimer, M.; Seyedmahmoudian, M.; Horan, B.; Stojcevski, A. Investigating the Role of Virtual Reality in Planning for Sustainable Smart Cities. Sustainability 2017, 9, 2006. [CrossRef]

34. Ma, Y.; Wright, J.; Gopal, S.; Phillips, N. Seeing the invisible: From imagined to virtual urban landscapes. Cities 2020, 98, 1-10. [CrossRef]

35. Maffei, L.; Masullo, M.; Pascale, A.; Ruggiero, G.; Puyana-Romero, V. Immersive virtual reality in community planning: Acoustic and visual congruence of simulated vs real world. Sustain. Cities Soc. 2016, 27, 338-345. [CrossRef]

36. Edler, D.; Keil, J.; Wiedenlübbert, T.; Sossna, M.; Kühne, O.; Dickmann, F. Immersive VR Experience of Redeveloped Postindustrial Sites: The Example of "Zeche Holland" in Bochum-Wattenscheid. KN J. Cartogr. Geogr. Inf. 2019, 38, 1-18. [CrossRef]

37. Berger, M.; Bill, R. Combining VR Visualization and Sonification for Immersive Exploration of Urban Noise Standards. MTI Multimodal Technol. Interact. 2019, 3, 34. [CrossRef]

38. Edler, D.; Kühne, O.; Keil, J.; Dickmann, F. Audiovisual Cartography: Established and New Multimedia Approaches to Represent Soundscapes. KN J. Cartogr. Geogr. Inf. 2019, 69, 5-17. [CrossRef]

39. Huang, J.; Lucash, M.S.; Scheller, R.M.; Klippel, A. Walking through the forests of the future: Using data-driven virtual reality to visualize forests under climate change. Int. J. Geogr. Inf. Sci. 2020, 35, 1155-1178. [CrossRef]

40. Dickmann, F. Die kartographische Darstellung von Landschaftsprozessen. In Landschaft als Prozess; Duttmann, R., Kühne, O., Weber, F., Eds.; Springer: Wiesbaden, Germany, 2020; pp. 225-244.

41. Büyüksalih, G.; Kan, T.; Özkan, G.E.; Meriç, M.; Isın, L.; Kersten, T.P. Preserving the Knowledge of the Past Through Virtual Visits: From 3D Laser Scanning to Virtual Reality Visualisation at the Istanbul Çatalca İnceğiz Caves. PFG J. Photogramm. Remote. Sens. Geoinf. Sci. 2020, 88, 133-146. [CrossRef] 
42. Medyńska-Gulij, B.; Zagata, K. Experts and Gamers on Immersion into Reconstructed Strongholds. ISPRS Int. J. Geo Inf. 2020, 9, 655. [CrossRef]

43. Walmsley, A.; Kersten, T.P. The Imperial Cathedral in Königslutter (Germany) as an Immersive Experience in Virtual Reality with Integrated $360^{\circ}$ Panoramic Photography. J. Appl. Sci. 2020, 10, 1517. [CrossRef]

44. Zhao, J.; LaFemina, P.; Carr, J.; Sajjadi, P.; Wallgrün, J.O.; Klippel, A. Learning in the Field: Comparison of Desktop, Immersive Virtual Reality, and Actual Field Trips for Place-Based STEM Education. In Proceedings of the 2020 IEEE Conference on Virtual Reality and 3D User Interfaces (VR), Atlanta, GA, USA, 22-26 March 2020.

45. Šašinka, Č.; Stachǒn, Z.; Sedlák, M.; Chmelík, J.; Herman, L.; Kubíček, P.; Šašinková, A.; Doležal, M.; Tejkl, H.; Urbánek, T.; et al. Collaborative Immersive Virtual Environments for Education in Geography. ISPRS Int. J. Geo Inf. 2019, 8, 3. [CrossRef]

46. Jerald, J. The VR Book: Human-Centered Design for Virtual Reality; Morgan \& Claypool: San Rafael, CA, USA, 2016.

47. Montello, D.R. Cognitive Map-Design Research in the Twentieth Century: Theoretical and Empirical Approaches. Cartogr. Geogr. Inf. Sci. 2002, 29, 282-304. [CrossRef]

48. Griffin, A.L.; Fabrikant, S.I. More Maps, More Users, More Devices Means More Cartographic Challenges. Cartogr. J. 2012, 49, 298-301. [CrossRef]

49. Dickmann, F.; Edler, D.; Bestgen, A.-K.; Kuchinke, L. Spatial Distortions in Cognitive Maps-A Chance and Challenge to Enrich the Principles of Map Design. KN J. Cartogr. Geogr. Inf. 2013, 63, 174-181. [CrossRef]

50. Epstein, R.A.; Patai, E.Z.; Julian, J.B.; Spiers, H.J. The cognitive map in humans: Spatial navigation and beyond. Nat. Neurosci. 2017, 20, 1504-1513. [CrossRef]

51. Lokka, I.E.; Çöltekin, A. Toward optimizing the design of virtual environments for route learning: Empirically assessing the effects of changing levels of realism on memory. Int. J. Digit. Earth 2019, 12, 137-155. [CrossRef]

52. Zagata, K.; Gulij, J.; Halik, Ł.; Medynska-Gulij, B. Mini-Map for Gamers Who Walk and Teleport in a Virtual Stronghold. ISPRS Int. J. Geo-Inf. 2021, 10, 96. [CrossRef]

53. Boletsis, C.; Cedergren, J.E. VR Locomotion in the New Era of Virtual Reality: An Empirical Comparison of Prevalent Techniques. Adv. Hum. Comput. Interact. 2019, 2019, 7420781. [CrossRef]

54. Cherep, L.A.; Lim, A.F.; Kelly, J.W.; Acharya, D.; Velasco, A.; Bustamante, E.; Ostrander, A.G.; Gilbert, S.B. Spatial cognitive implications of teleporting through virtual environments. J. Exp. Psychol. Appl. 2020, 26, 480-492. [CrossRef]

55. Lokka, I.E.; Çöltekin, A. Perspective switch and spatial knowledge acquisition: Effects of age, mental rotation ability and visuospatial memory capacity on route learning in virtual environments with different levels of realism. Cartogr. Geogr. Inf. Sci. 2020, 47, 14-27. [CrossRef]

56. Lokka, I.E.; Çöltekin, A.; Wiener, J.; Fabrikant, S.I.; Röcke, C. Virtual environments as memory training devices in navigational tasks for older adults. Sci. Rep. 2018, 8, 1-15. [CrossRef]

57. Winchester, H.P.M.; Kong, L.; Dunn, K. Landscapes: Ways of Imagining the World; Routledge: London, UK; New York, NY, USA, 2003.

58. Bourassa, S.C. The Aesthetics of Landscape; Belhaven Press: London, UK, 1991.

59. Panelli, R. Approaches to Human Geography: Philosophies, Theories, People and Practices; Aitken, S.C., Valentine, G., Eds.; SAGE: Los Angeles, CA, USA, 2015.

60. Howard, P.; Thompson, I.; Waterton, E. (Eds.) The Routledge Companion to Landscape Studies; Routledge: London, UK; New York, NY, USA, 2013.

61. Kühne, O.; Weber, F.; Berr, K.; Jenal, C. (Eds.) Handbuch Landschaft; Springer: Wiesbaden, Germany, 2019.

62. Gailing, L.; Leibenath, M. Von der Schwierigkeit, „Landschaft“ oder „Kulturlandschaft“ allgemeingültig zu definieren. Raumforsch. Raumordn. 2012, 70, 95-106. [CrossRef]

63. Tress, B.; Tress, G. Begriff, Theorie und System der Landschaft: Ein transdisziplinärer Ansatz zur Landschaftsforschung. Nat. Landsch. 2001, 33, 52-58.

64. Kühne, O. Landschaftstheorie und Landschaftspraxis: Eine Einführung aus Sozialkonstruktivistischer Perspektive; Springer: Wiesbaden, Germany, 2018.

65. Egner, H. Theoretische Geographie; WBG: Darmstadt, Germany, 2010.

66. Fernández, A.; Iván, P.; Buchroithner, M.F. Paradigms in Cartography: An Epistemological Review of the 20th and 21st Centuries; Springer: Berlin/Heidelberg, Germany, 2014.

67. Chilla, T.; Kühne, O.; Weber, F.; Weber, F. „Neopragmatische“ Argumente zur Vereinbarkeit von konzeptioneller Diskussion und Praxis der Regionalentwicklung. In Bausteine der Regionalentwicklung; Kühne, O., Weber, F., Eds.; Springer: Wiesbaden, Germany, 2015; pp. 13-24.

68. Schultze, J.H. Landschaft (1966/70). In Das Wesen der Landschaft; Paffen, K., Ed.; WBG: Darmstadt, Germany, 1973; pp. $202-222$.

69. Tilley, C. A Phenomenology of Landscape: Places, Paths and Monuments; Berg: Oxford, UK; Providence, RI, USA, 1997; ISBN 9781859730768.

70. Kühne, O. Zwischen Macht und Essenz, Konstrukt und Objekt?: Wie Landschaftstheorien Deutungskonkurrenzen von Natur zeigen. Stadt Grün 2019, 68, 24-27.

71. Cosgrove, D. Social Formation and Symbolic Landscape; University of Wisconsin Press: London, UK; Sydney, NSW, Australia, 1984; ISBN 9780299155148. 
72. Greider, T.; Garkovich, L. Landscapes: The Social Construction of Nature and the Environment. Rural. Sociol. 1994, 59, 1-24. [CrossRef]

73. Kühne, O. Die Sozialisation von Landschaft-Sozialkonstruktivistische Überlegungen, empirische Befunde und Konsequenzen für den Umgang mit dem Thema Landschaft in Geographie und räumlicher Planung. Geogr. Z. 2008, 96, $189-206$.

74. Lippuner, R. Raumbilder der Gesellschaft. Zur Räumlichkeit des Sozialen in der Systemtheorie. In Spatial Turn: Das Raumparadigma in den Kultur- und Sozialwissenschaften; Döring, J., Thielmann, T., Eds.; Transcript Verlag: Bielefeld, Germany, 2008; pp. 341-363, ISBN 3899426835.

75. Luhmann, N. Ökologische Kommunikation: Kann die Moderne Gesellschaft sich auf Ökologische Gefährdungen Einstellen? Westdeutscher Verlag: Opladen, Germany, 1986; ISBN 3-531-11775-0.

76. van Assche, K.; Verschraegen, G. The Limits of Planning: Niklas Luhmann's Systems Theory and the Analysis of Planning and Planning Ambitions. Plan. Theory 2008, 7, 263-283. [CrossRef]

77. Redepenning, M.; Wilhelm, J. Raumforschung mit luhmannscher Systemtheorie. In Theorien in der Raum-und Stadtforschung: Einführungen; Oßenbrügge, J., Vogelpohl, A., Eds.; Westfälisches Dampfboot: Münster, Germany, 2014; pp. 310-327, ISBN 9783896919649.

78. Kühne, O. Das Konzept der Ökosystemdienstleistungen als Ausdruck ökologischer Kommunikation: Betrachtungen aus der Perspektive Luhmannscher Systemtheorie. Nat. Landsch. 2014, 46, 17-22.

79. Keller, R. Diskursforschung: Eine Einführung für SozialwissenschaftlerInnen; VS Verlag für Sozialwissenschaften: Wiesbaden, Germany, 2007; ISBN 978-3531154596.

80. Keller, R. Wissenssoziologische Diskursanalyse: Grundlegung eines Forschungsprogramms; VS Verlag für Sozialwissenschaften: Wiesbaden, Germany, 2011; ISBN 978-3-531-92058-0.

81. Foucault, M. Archäologie des Wissens; Suhrkamp: Frankfurt (Main), Germany, 1981; ISBN 978-3-518-27956-4.

82. Habermas, J. Theorie des Kommunikativen Handelns: Band I. Handlungsrationalität und Gesellschaftliche Rationalisierung; Suhrkamp: Frankfurt (Main), Germany, 1995; ISBN 978-3-518-28775-0.

83. Laclau, E.; Mouffe, C. Hegemony and Socialist Strategy: Towards a Radical Democratic Politics; Verso: London, UK; New York, NY, USA, 1985; ISBN 0860910679.

84. Leibenath, M.; Otto, A. Windräder in Wolfhagen-Eine Fallstudie zur diskursiven Konstituierung von Landschaften. In Wie werden Landschaften gemacht?: Sozialwissenschaftliche Perspektiven auf die Konstituierung von Kulturlandschaften; Leibenath, M., Heiland, S., Kilper, H., Tzschaschel, S., Eds.; Transcript Verlag: Bielefeld, Germany, 2013; pp. 205-236, ISBN 978-3-8376-1994-2.

85. Weber, F. Landschaftskonflikte' aus poststrukturalistisch-diskurstheoretischer Perspektive. In Landschaftskonflikte; Berr, K., Jenal, C., Eds.; Springer: Wiesbaden, Germany, 2019; pp. 51-64, ISBN 978-3-658-22325-0.

86. Leibenath, M.; Otto, A. Competing Wind Energy Discourses, Contested Landscapes. Landsc. Online 2014, 1-18. [CrossRef]

87. Waterton, E. Landscape and non-representational theories. In The Routledge Companion to Landscape Studies; Howard, P., Thompson, I., Waterton, E., Eds.; Routledge: London, UK; New York, NY, USA, 2013; pp. 66-75, ISBN 9780415096925.

88. Lorimer, H. Cultural geography: The busyness of being 'more-than-representational'. Prog. Hum. Geogr. 2005, 29, 83-94. [CrossRef]

89. Wylie, J. A single day's walking: Narrating self and landscape on the South West Coast Path. Trans. Inst. Br. Geogr. 2005, 30, 234-247. [CrossRef]

90. Tuan, Y.-F. Surface Phenomena and Aesthetic Experience. Ann. Assoc. Am. Geogr. 1989, 79, 233-241. [CrossRef]

91. Latour, B.; Roßler, G. Eine neue Soziologie für eine neue Gesellschaft: Einführung in die Akteur-Netzwerk-Theorie; Suhrkamp: Frankfurt (Main), Germany, 2007; ISBN 978-3-518-58488-0.

92. Latour, B. Petite Réflexion sur le Culte Moderne des Dieux Faitiches; Synthélabo Groupe: Le Plessis-Robinson, France, 1996; ISBN 2908602768.

93. Latour, B. The Trouble with Actor-Network Theory. Soziale Welt 1997, 47, 369-381.

94. Schulz-Schaeffer, I. Akteur-Netzwerk-Theorie: Zur Koevolution von Gesellschaft, Natur und Technik. In Soziale Netzwerke: Konzepte und Methoden der Sozialwissenschaftlichen Netzwerkforschung; Weyer, J., Abel, J., Eds.; Oldenbourg: München, Germany, 2000; pp. 187-210, ISBN 3-486-25257-7.

95. Latour, B.; Woolgar, S. Laboratory Life: The Construction of Scientific Facts; Princeton University Press: Princeton, NJ, USA, 2013; ISBN 9781400820412.

96. Gertenbach, L. Entgrenzungen der Soziologie: Bruno Latour und der Konstruktivismus; Velbrück: Weilerswist, Germany, 2015; ISBN 978-3-95832-049-9.

97. Mattissek, A.; Wiertz, T. Materialität und Macht im Spiegel der Assemblage-Theorie: Erkundungen am Beispiel der Waldpolitik in Thailand. Geogr. Helv. 2014, 69, 157-169. [CrossRef]

98. Soja, E.W. Verräumlichungen: Marxistische Geographie und kritische Gesellschaftstheorie. In Raumproduktionen: Beiträge der Radical Geography. Eine Zwischenbilanz; Belina, B., Michel, B., Eds.; Westfälisches Dampfboot: Münster, Germany, 2007; pp. 77-110, ISBN 3-89691-659-9.

99. Samers, M.; Bigger, P.; Belcher, O. To Build Another World: Activism in the Light of Marxist Geographical Thougt. In Approaches to Human Geography: Philosophies, Theories, People and Practices; Aitken, S.C., Valentine, G., Eds.; SAGE: Los Angeles, CA, USA, 2015; pp. 344-360, ISBN 9781446276020. 
100. Kemper, J.; Wiegand, F. Marxistische Stadtforschung. In Theorien in der Raum- und Stadtforschung: Einführungen; Oßenbrügge, J., Vogelpohl, A., Eds.; Westfälisches Dampfboot: Münster, Germany, 2014; pp. 215-233, ISBN 9783896919649.

101. Lefebvre, H. La production de l'espace. L'Homme Et La Société 1974, 31-32, 15-32. [CrossRef]

102. Lefebvre, H. Le Droit à la Ville Suivi de Espace et Politique; Édition Anthropos: Paris, France, 1972; ISBN 9782020006279.

103. Daniels, S. Marxism, Culture, and the Duplicity of Landscape. In New Models in Geography Vol. 2: The Political-Economy Perspective; Peet, R., Thrift, N., Eds.; Unwin Hyman: London, UK, 1989; pp. 196-220, ISBN 004445421X.

104. Schein, R.H. The Place of Landscape: A Conceptual Framework for Interpreting an American Scene. Ann. Assoc. Am. Geogr. 1997, 87, 660-680. [CrossRef]

105. Horkheimer, M.; Adorno, T.W. Dialektik der Aufklärung: Philosophische Fragmente; Fischer: Frankfurt (Main), Germany, 1969; ISBN 9783596274048.

106. Crampton, J.; Krygier, J. An Introduction to Critical Cartography. ACME Int. J. Crit. Geogr. 2005, 4, 11-33.

107. Bourdieu, P. Die Feinen Unterschiede. Kritik der Gesellschaftlichen Urteilskraft; Suhrkamp: Frankfurt (Main), Germany, 1987; ISBN 9783518282588.

108. Kühne, O. Kritische Geographie der Machtbeziehungen-Konzeptionelle Überlegungen auf der Grundlage der Soziologie Pierre Bourdieus. Geogr. Rev. 2008, 10, 40-50.

109. Morrow, V. Young people's explanations and experiences of social exclusion: Retrieving Bourdieu's concept of social capital. Int. J. Sociol. Soc. Policy 2001, 21, 37-63. [CrossRef]

110. Bourdieu, P. Ökonomisches Kapital-Kulturelles Kapital-Soziales Kapital. In Die Verborgenen Mechanismen der Macht; Bourdieu, P., Ed.; VSA: Hamburg, Germany, 2005; pp. 49-80, ISBN 9783899656879.

111. Dahrendorf, R. Sozialer Konflikt. In Wörterbuch der Soziologie; Bernsdorf, W., Ed.; Ferdinand Enke Verlag: Stuttgart, Germany, 1969; pp. 1006-1009.

112. Dahrendorf, R. Soziale Klassen und Klassenkonflikt in der Industriellen Gesellschaft; Enke: Stuttgart, Germany, 1957.

113. Dahrendorf, R. Zu einer Theorie des Sozialen Konflikts [1958 erstveröffentlicht]. In Theorien des Sozialen Wandels; Zapf, W., Ed.; Kiepenheuer \& Witsch: Köln, Germany, 1969; pp. 108-123.

114. Dahrendorf, R. Konflikt und Freiheit: Aufdem Weg zur Dienstklassengesellschaft; Piper: München, Germany, 1972; ISBN 9783492017824.

115. Dahrendorf, R. Der Moderne Soziale Konflikt: Essay zur Politik der Freiheit; Deutsche Verlags-Anstalt: Stuttgart, Germany, 1992; ISBN 3-421-06539-X.

116. Kühne, O. Die Produktivität von Landschaftskonflikten-Möglichkeiten und Grenzen auf Grundlage der Konflikttheorie Ralf Dahrendorfs. In Landschaftskonflikte; Berr, K., Jenal, C., Eds.; Springer: Wiesbaden, Germany, 2019; pp. 37-49, ISBN 978-3-658-22325-0.

117. Kühne, O. Landscape Conflicts: A Theoretical Approach Based on the Three Worlds Theory of Karl Popper and the Conflict Theory of Ralf Dahrendorf, Illustrated by the Example of the Energy System Transformation in Germany. Sustainability 2020, 12, 6772. [CrossRef]

118. Weber, F.; Kühne, O.; Jenal, C.; Aschenbrand, E.; Artuković, A. Sand im Getriebe: Aushandlungsprozesse um die Gewinnung Mineralischer Rohstoffe aus Konflikttheoretischer Perspektive nach Ralf Dahrendorf; Springer: Wiesbaden, Germany, 2018; ISBN 978-3-658-21526-2.

119. Goffman, E. Frame Analysis: An Essay on the Organization of Experience; Harper \& Row: New York, NY, USA, 1974 ; ISBN 0060903724.

120. Shmueli, D.F.; Ben-Gal, M. The Potential of Framing in Managing and Resolving Environmental Conflict. In Advancing Sustainability at the Sub-National Level: The Potential and Limitations of Planning; Faitelson, E., Ed.; Ashgate Press: Aldershot, UK, 2004; pp. 197-217, ISBN 0754638871.

121. Shmueli, D.F. Framing in geographical analysis of environmental conflicts: Theory, methodology and three case studies. Geoforum 2008, 39, 2048-2061. [CrossRef]

122. Kaufman, S.; Shmueli, D.F. Framing in Public Decision Interactions: Transferring theory to practice. In Framing Matters: Perspectives on Negotiation Research and Practice in Communication; Donohue, W.A., Kaufman, S., Rogan, R.G., Eds.; Peter Lang Publishing: New York, NY, USA, 2011; pp. 167-190, ISBN 9781433111488.

123. Lewicki, R.J.; Saunders, D.M.; Minton, J.W. Negotiation: Readings, Exercises, and Cases: Instructor's Manual, 3rd ed.; Irwin McGraw-Hill: Boston, MA, USA, 1999; ISBN 0-07-059346-9.

124. Neale, M.A.; Bazerman, M.H. The Effects of Framing and Negotiator Overconfidence on Bargaining Behaviors and Outcomes. AMJ Acad. Manag. J. 1985, 28, 34-49. [CrossRef]

125. Coman, R. Values and Power Conflicts in Framing Borders and Borderlands: The 2013 Reform of EU Schengen Governance. J. Borderl. Stud. 2019, 34, 685-698. [CrossRef]

126. Díez Medrano, J. Framing Europe: Attitudes to European integration in Germany, Spain, and the United Kingdom; Princeton University Press: Princeton, NJ, USA, 2010; ISBN 9780691146508.

127. Marcinkowski, F. (Ed.) Framing als Politischer Prozess: Beiträge zum Deutungskampf in der Politischen Kommunikation; Nomos: Baden-Baden, Germany, 2014; ISBN 978-3-8487-0238-1.

128. Kepplinger, H.M.; Lemke, R. Framing Fukushima: Zur Darstellung der Katastrophe in Deutschland im Vergleich zu Großbritannien, Frankreich und der Schweiz. In Fukushima und die Folgen: Medienberichterstattung, Öffentliche Meinung, Politische Konsequenzen; Wolling, J., Arlt, D., Eds.; Universitäts-Verlag Ilmenau: Ilmenau, Germany, 2014; pp. 125-152, ISBN 978-3-86360-100-3.

129. Squire, K. Cultural Framing of Computer/Video Games. Game Stud. 2002, 2, 1-13. 
130. Kaufman, S.; Smith, J. Framing and Reframing in Land Use Change Conflicts. J. Archit. Plan. Res. 1999, 16, 164-180.

131. Shmueli, D.F.; Gal, M.B. Creating Environmental Stakeholder Profiles: A Tool for Dispute Management. Environ. Practice 2005, 7, 165-175. [CrossRef]

132. Berr, K.; Jenal, C.; Kühne, O.; Weber, F. Inter- und Transdisziplinäre Landschaftsforschung. In Handbuch Landschaft; Kühne, O., Weber, F., Berr, K., Jenal, C., Eds.; Springer: Wiesbaden, Germany, 2019; pp. 165-180.

133. Denzin, N.K. Triangulation. In The Blackwell Encyclopedia of Sociology; Ritzer, G., Ed.; John Wiley \& Sons, Ltd.: Oxford, UK, 2007; ISBN 9781405168182

134. Schründer-Lenzen, A. Triangulation-Ein Konzept zur Qualitätssicherung von Forschung. In Handbuch: Qualitative Forschungsmethoden in der Erziehungswissenschaft; Friebertshäuser, B., Langer, A., Prengel, A., Eds.; Beltz Juventa: Weinheim, Germany, 2013; pp. 149-158, ISBN 9783779907992.

135. Kühne, O.; Jenal, C. Baton Rouge-A Neopragmatic Regional Geographic Approach. Urban Sci. 2021, 5, 17. [CrossRef]

136. Kühne, O.; Jenal, C. Baton Rouge-The Multivillage Metropolis: A Neopragmatic Landscape Biographical Approach on Spatial Pastiches, Hybridization, and Differentiation; Springer: Wiesbaden, Germany, 2020; ISBN 978-3-658-30716-5.

137. Eckardt, F. Stadtforschung: Gegenstand und Methoden; Springer: Wiesbaden, Germany, 2014; ISBN 9783658008239.

138. Kühne, O.; Jenal, C. Baton Rouge (Louisiana): On the Importance of Thematic Cartography for 'Neopragmatic Horizontal Geography'. KN J. Cartogr. Geogr. Inf. 2020, 71, 23-31. [CrossRef]

139. Edler, D. Where Spatial Visualization Meets Landscape Research and "Pinballology": Examples of Landscape Construction in Pinball Games. KN J. Cartogr. Geogr. Inf. 2020, 70, 55-59. [CrossRef]

140. Tschirschwitz, F.; Richerzhagen, C.; Przybilla, H.-J.; Kersten, T.P. Duisburg 1566: Transferring a Historic 3D City Model from Google Earth into a Virtual Reality Application. PFG J. Photogramm. Remote. Sens. Geoinf. Sci. 2019, 87, 47-56. [CrossRef]

141. Smaczyński, M.; Horbiński, T. Creating a 3D Model of the Existing Historical Topographic Object Based on Low-Level Aerial Imagery. KN J. Cartogr. Geogr. Inf. 2021, 72, 33-43. [CrossRef]

142. Çöltekin, A.; Oprean, D.; Wallgrün, J.O.; Klippel, A. Where are we now? Re-visiting the Digital Earth through human-centered virtual and augmented reality geovisualization environments. Int. J. Digit. Earth 2019, 12, 119-122. [CrossRef]

143. Keil, J.; Edler, D.; O'Meara, D.; Korte, A.; Dickmann, F. Effects of Virtual Reality Locomotion Techniques on Distance Estimations. ISPRS Int. J. Geo Inf. 2021, 10, 150. [CrossRef]

144. Hruby, F. The Sound of Being There: Audiovisual Cartography with Immersive Virtual Environments. KN J. Cartogr. Geogr. Inf. 2019, 69, 19-28. [CrossRef]

145. Kühne, O. Die Sozialisation von Landschaft. In Handbuch Landschaft; Kühne, O., Weber, F., Berr, K., Jenal, C., Eds.; Springer: Wiesbaden, Germany, 2019; pp. 301-312, ISBN 978-3-658-25746-0.

146. Stotten, R. Kulturlandschaft gemeinsam verstehen-Praktische Beispiele der Landschaftssozialisation aus dem Schweizer Alpenraum. Geogr. Helv. 2013, 68, 117-127. [CrossRef]

147. Nissen, U. Kindheit, Geschlecht und Raum: Sozialisationstheoretische Zusammenhänge Geschlechtsspezifischer Raumaneignung; Beltz Juventa: Weinheim, Germany, 1998; ISBN 9783779901990.

148. Berr, K. Zur Moral des Bauens, Wohnens und Gebauten. In Architektur- und Planungsethik: Zugänge, Perspektiven, Standpunkte; Berr, K., Ed.; Springer: Wiesbaden, Germany, 2017; pp. 111-138, ISBN 978-3-658-14972-7.

149. Berr, K.; Kühne, O. Moral und Ethik von Landschaft. In Handbuch Landschaft; Kühne, O., Weber, F., Berr, K., Jenal, C., Eds.; Springer: Wiesbaden, Germany, 2019; pp. 351-365, ISBN 978-3-658-25746-0.

150. Kühne, O. Die Moralisierung von Landschaft-Überlegungen zu einer problematischen Kommunikation aus Sicht der Luhmannschen Systemtheorie. In Diedrich Bruns Wird Gelehrt Haben: Eine Festschrift; Hennecke, S., Kegler, H., Klaczynski, K., Münderlein, D., Eds.; Kassel University Press: Kassel, Germany, 2018; pp. 115-121, ISBN 9783737650649.

151. Luhmann, N. Die Moral des Risikos und das Risiko der Moral. In Risiko und Gesellschaft: Grundlagen und Ergebnisse Interdisziplinärer Risikoforschung; Bechmann, G., Ed.; Westdeutscher Verlag: Opladen, Germany, 1993; pp. 327-338, ISBN 978-3-322-90741-7.

152. Grau, A. Hypermoral: Die neue Lust an der Empörung; Claudius: München, Germany, 2017; ISBN 9783532628034.

153. Burckhardt, L. Spaziergangswissenschaft (1995). In Warum ist Landschaft schön? Die Spaziergangswissenschaft; Ritter, M., Schmitz, M., Eds.; Martin Schmitz Verlag: Kassel, Germany, 2006; pp. 257-300, ISBN 9783927795426.

154. Keil, J.; Korte, A.; Ratmer, A.; Edler, D.; Dickmann, F. Augmented Reality (AR) and Spatial Cognition: Effects of Holographic Grids on Distance Estimation and Location Memory in a 3D Indoor Scenario. PFG J. Photogramm. Remote. Sens. Geoinf. Sci. 2020, 88, 165-172. [CrossRef]

155. Horkheimer, M. Critical Theory: Selected Essays; Continuum: New York, NY, USA, 1982; ISBN 9780826400833.

156. Chapman, A. Is Sid Meier's Civilization history? Rethink. Hist. 2013, 17, 312-332. [CrossRef]

157. Ford, D. "eXplore, eXpand, eXploit, eXterminate": Affective Writing of Postcolonial History and Education in Civilization V. Available online: http:/ / gamestudies.org/1602/articles/ford (accessed on 30 July 2021).

158. Pobłocki, K. Becoming-state: The bio-cultural imperialism of Sid Meier's Civilization. Focaal Eur. J. Anthropol. 2002, 39, 163-177.

159. Vrtačič, E. The grand narratives of video games: Sid Meier's Civilization. Teorija Praksa 2014, 51, 91-105.

160. Honneth, A. Die Idee des Sozialismus: Versuch Einer Aktualisierung; Suhrkamp: Berlin, Germany, $2015 ;$ ISBN 9783518586785.

161. Burns, A. Civilization III: Digital Game-Based Learning an Macrohistory Simulations. Retrieved 2004, 11, 1-16.

162. Lee, J.K.; Probert, J. Civilization III and Whole-Class Play in High School Social Studies. J. Soc. Stud. Res. 2010, 34, 1-28.

163. Merton, R.K. Social Theory and Social Structure; Free Press: New York, NY, USA, 1968; ISBN 9780029211304. 
164. Merton, R.K. The Sociology of Science: Theoretical and Empirical Investigations; University of Chicago Press: Chicago, IL, USA, 1973; ISBN 0226520927.

165. Flick, U. Triangulation; Springer Fachmedien: Wiesbaden, Germany, 2011; ISBN 9783531181257.

166. Böse, H.; Stemmer, B.; Moczek, N.; Hofmann, M. Die Bedeutung der Ortsidentität für die Landschaftswahrnehmung am Beispiel von Windenergieanlagen. In Heimat: Ein vielfältiges Konstrukt; Hülz, M., Kühne, O., Weber, F., Eds.; Springer: Wiesbaden, Germany, 2019; pp. 179-202, ISBN 978-3-658-24161-2.

167. Stemmer, B.; Bruns, D. Kooperative Landschaftsbewertung in der räumlichen Planung—Planbare Schönheit? Partizipative Methoden, (Geo-)Soziale Medien. In Landschaftsästhetik und Landschaftswandel; Kühne, O., Megerle, H., Weber, F., Eds.; Springer: Wiesbaden, Germany, 2017; pp. 283-302, ISBN 978-3-658-15848-4.

168. Lim, E.-M.; Honjo, T.; Umeki, K. The validity of VRML images as a stimulus for landscape assessment. Landsc. Urban Plan. 2006, 77, 80-93. [CrossRef]

169. Lange, E. Integration of computerized visual simulation and visual assessment in environmental planning. Landsc. Urban Plan. 1994, 30, 99-112. [CrossRef]

170. Kühne, O. Contours of a 'Post-Critical' Cartography-A Contribution to the Dissemination of Sociological Cartographic Research. KN J. Cartogr. Geogr. Inf. 2021. [CrossRef]

171. Popper, K.R. Three Worlds: Tanner Lecture, Michigan, April 7, 1978. Mich. Q. Rev. 1979, 18, 141-167.

172. Popper, K.R.; Eccles, J.C. Das Ich und Sein Gehirn; Piper: München, Germany, 1977; ISBN 3-492-02447-5. 